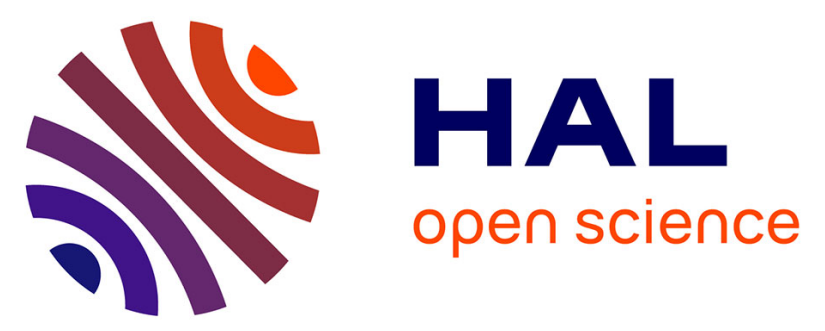

\title{
NKX2-5: An Update on this Hypermutable Homeodomain Protein and its Role in Human Congenital Heart Disease (CHD)
}

\author{
Stella Marie Reamon-Buettner, Juergen T Borlak
}

\section{- To cite this version:}

Stella Marie Reamon-Buettner, Juergen T Borlak. NKX2-5: An Update on this Hypermutable Homeodomain Protein and its Role in Human Congenital Heart Disease (CHD). Human Mutation, 2010, 31 (11), pp.1185. 10.1002/humu.21345 . hal-00585168

\section{HAL Id: hal-00585168 \\ https://hal.science/hal-00585168}

Submitted on 12 Apr 2011

HAL is a multi-disciplinary open access archive for the deposit and dissemination of scientific research documents, whether they are published or not. The documents may come from teaching and research institutions in France or abroad, or from public or private research centers.
L'archive ouverte pluridisciplinaire HAL, est destinée au dépôt et à la diffusion de documents scientifiques de niveau recherche, publiés ou non, émanant des établissements d'enseignement et de recherche français ou étrangers, des laboratoires publics ou privés. 
NKX2-5: An Update on this Hypermutable Homeodomain Protein and its Role in Human Congenital Heart Disease (CHD)

\begin{tabular}{|c|c|}
\hline Journal: & Human Mutation \\
\hline Manuscript ID: & humu-2010-0256.R1 \\
\hline Wiley - Manuscript type: & Review \\
\hline $\begin{array}{l}\text { Date Submitted by the } \\
\text { Author: }\end{array}$ & $15-J u l-2010$ \\
\hline Complete List of Authors: & $\begin{array}{l}\text { Reamon-Buettner, Stella Marie; Fraunhofer Institute of Toxicology } \\
\text { and Experimental Medicine, Molecular Medicine and Medical } \\
\text { Biotechnology } \\
\text { Borlak, Juergen; Fraunhofer Institute of Toxicology and } \\
\text { Experimental Medicine, Molecular Medicine and Medical } \\
\text { Biotechnology }\end{array}$ \\
\hline Key Words: & $\begin{array}{l}\text { heart development, congenital heart disease, cardiac } \\
\text { malformations, transcription factors, NKX2-5, mutations }\end{array}$ \\
\hline
\end{tabular}

\section{SCHOLARONE ${ }^{\text {Tw }}$ \\ Manuscripts}




\section{NKX2-5: An Update on this Hypermutable Homeodomain Protein and its Role in Human Congenital Heart Disease (CHD)}

Stella Marie Reamon-Buettner and Juergen Borlak*

Molecular Medicine and Medical Biotechnology, Fraunhofer Institute of Toxicology and Experimental Medicine, Nikolai-Fuchs-Strasse 1, D-30625 Hannover, Germany.

*Correspondence to Prof. Dr. Juergen Borlak, Molecular Medicine and Medical Biotechnology, Fraunhofer Institute of Toxicology and Experimental Medicine, NikolaiFuchs-Strasse 1, 30625 Hannover, Germany.

Tel: +49-511-5350-559; Fax +49-511-5350-573; E-mail: borlak@item.fraunhofer.de Contract grant sponsors: Ministry of Science and Culture, Lower Saxony, Germany; Contract grant number: 25A.5-76251-99-3/00 
Keywords: heart development, congenital heart disease, cardiac malformations, transcription factors, $N K X 2-5$, mutations

\begin{abstract}
Congenital heart disease (CHD) is among the most prevalent and fatal of all birth defects.

Deciphering its causes, however, is complicated as many patients affected by CHD have no family history of the disease. There is also widespread heterogeneity of cardiac malformations among affected individuals. Nonetheless, there have been tremendous efforts towards a better understanding of the molecular and cellular events leading to CHD. Notably, certain cardiacspecific transcription factors have been implicated in mammalian heart development and disruption of their activity has been demonstrated in CHD. The homeodomain transcription factor NKX2-5 is an important member of this group. Indeed, more than 40 heterozygous NKX2-5 germline mutations have been observed in individuals with CHD and these are spread along the coding region, with many shown to impact protein function. Thus, NKX2-5 appears to be hypermutable (?) highly mutable, yet the overall detection frequency in sporadic CHD is about $2 \%$ and NKX2-5 mutations are one-time detections with single-positives or private to families. Furthermore, there is lack of genotype-phenotype correlation, in which the same cardiac malformations have been exhibited in different $N K X 2-5$ mutations or the same NKX2-5 mutation associated with diverse malformations. Here, we summarize published NKX2-5 germline mutations and explore different avenues in disease pathogenesis to support the notion of a multifactorial cause of CHD where possibly several genes and associated pathways are involved.
\end{abstract}

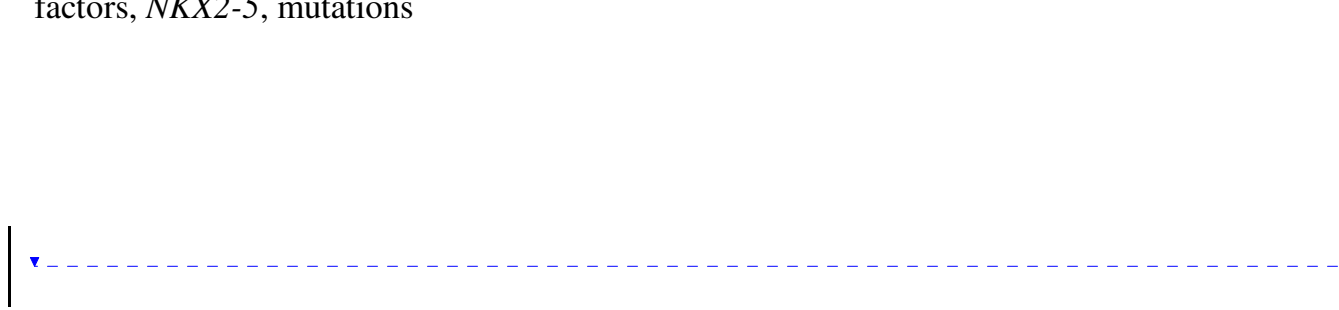
Deleted: ..........Page Break …...... II 
Dr. Mark Paalman

The Managing Editor

Human Mutation

Dear Dr. Paalman:

Many thanks for the encouraging news on our manuscript " NKX2-5: An Update on this Hypermutable Homeodomain Protein and its Role in Human Congenital Heart Disease (CHD)" Human Mutation Paper No. humu-2010-0256. Attached is the revised manuscript, as well as the response to the managing editor's comments.

We look forward to seeing our work published in Human Mutation.

Sincerely yours, JUERGEN BORLAK

RESPONSE TO MANAGING EDITOR'S COMMENTS

\begin{abstract}
1) The mutation nomenclature appears to follow the format indicated in the Author Instructions (see the website http://www.hgvs.org/mutnomen/ and also the nomenclature checklist at http://www.hgvs.org/mutnomen/checklist.html). Things to watch for:

a-Mention the GenBank reference sequence and version number for the gene(s) studied (i.e., include the decimal point following the accession number in the sequence record) in the Materials and Methods and as a footnote to the relevant tables and figure.

b-Clearly indicate in the Methods text and tables that the DNA mutation numbering system you use is based on cDNA sequence. Explanatory text is required in legends and text, for example:

"Nucleotide numbering reflects cDNA numbering with +1 corresponding to the $A$ of the ATG translation initiation codon in the reference sequence, according to journal guidelines (www.hgvs.org/mutnomen). The initiation codon is codon $1 . "$
\end{abstract}

\title{
RESPONSE:
}

The footnote below is incorporated in Table 1, Supp.Tables S2 and S3.

"Nucleotide numbering reflects $c D N A$ numbering with +1 corresponding to the A of the ATG translation initiation codon in the reference sequence NM_0004387.3, according to journal guidelines (www.hgvs.org/mutnomen). The initiation codon is codon 1."

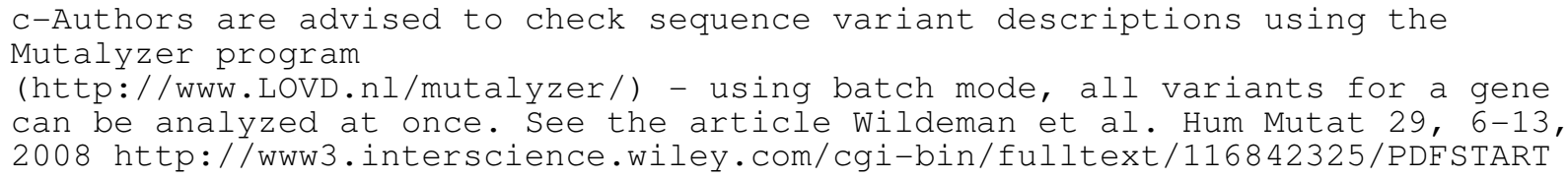

John Wiley \& Sons, Inc. 


\section{RESPONSE :}

The batch mode of Mutalyzer was used to check the list of NKX2-5 mutations.

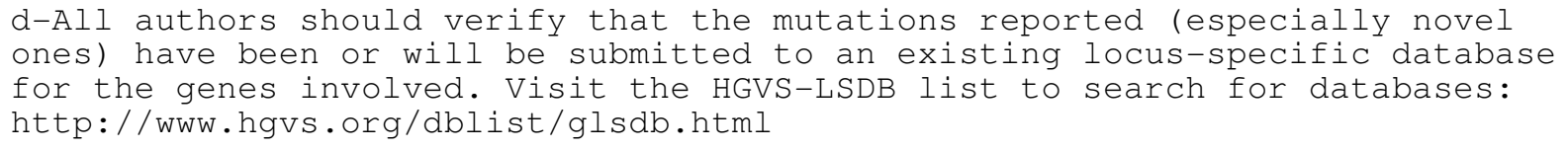

\section{RESPONSE:}

Review paper, and no novel mutations being reported.

2) On resubmission:

a-Please double check the author names and affiliations carefully. These are often a source of typographical errors.

\section{RESPONSE :}

Authors' names and affiliations checked.

b-Title Page, Abstract (180-200 words max), Key Words, Main Text, References, and Figure Legends should be combined into one file for the manuscript and submitted as a *.doc file.

\section{RESPONSE :}

The submitted*doc. file (NKX2-5 humu10-0256_text.doc) contains the specified components; Abstract is 200 words.

c-Figures for main article must be submitted as separate files with high resolution (at least $200 \mathrm{dpi}$ ) as *.tif or *.eps format only.

--For color figures in print: submit two files for each color figure: one in CMYK color space and one in RGB color space (with the true color you wish to have published). If you cannot provide CMYK color e-files for the print version, please let me know.

\section{RESPONSE :}

Figure 3 is 200 dpi, the rest are 300 dpi; both CMYK and RGB files for Figure 3 and Figure 4.

d-Tables must be submitted individually as separate *.doc files (with their titles and legends included). Please use the MS Word table format if possible. Excel (*.xls) files should not be submitted.

--Do not use custom paper sizes - only use Letter or A4.

\section{RESPONSE :}

Table 1. Functional Consequences of Identified NKX2-5 Mutations in CHD: Functional Assays or Bioinformatic Analysis is contained in *doc.file NKX2-5 humu10-0256_Table 1.doc.

Table 2. Detection Frequency of NKX2-5 Germline Mutations in Congenital Heart Disease is contained in *doc.file NKX2-5 humu10-0256_Table 2.doc.

e-Any Supporting Tables or Figures should be named and cited from the text as follows: 'Supp. Table S1' and 'Supp. Figure S1' (see below).

--If possible, do not use custom paper sizes - Letter or A4 are preferred.

\section{RESPONSE :}

As instructed Supplementary Materials are named in the text accordingly. 
f-Supporting Figures and Tables should be prepared in a single MS Word *.doc file labeled 'Supp_Mat', with Figures preceding Tables. Each table/figure should be accompanied with its legend.

\title{
RESPONSE :
}

The single file NKX2-5 humu10-0256_Supp_Mat. doc contains the following:

Supp. Figure S1. Geographical distribution of germline NKX2-5 mutations in CHD along the coding sequence of the gene; Supp. Table S1. Studies on NKX2-5 Mutations Associated with Congenital Heart Disease (CHD); Supp. Table S2. Summary of Published Germline NKX2-5 Mutations in Patients with Congenital Heart Defects; Supp. Table S3. Functional Significance of Published Germline NKX2-5 Mutations in Patients with Congenital Heart Disease

\begin{abstract}
3) Please check to see that the references follow the journal's standard format and are cited properly. All authors must be listed, for example. See our online Author Instructions http://www3.interscience.wiley.com/cgibin/jabout/38515/ForAuthors.html
\end{abstract}

\section{RESPONSE :}

References are according to journal's format and updated to the latest status of publication.

4) Figures 3 and 4 require color in the print version in order to be fully understood. We will offer you one free color print page. I think that both figures should fit on one color page. If any additional color is needed or desired, it would cost $\$ 500$ per page.

\section{RESPONSE :}

We are amenable to this suggestion, and many thanks for your offer of one free color print page.

5) Human Mutation can accommodate researchers funded by agencies requiring open access publication.More information on Wiley-Blackwell's policy is available at:

http://www.interscience.wiley.com/openaccess

\section{6) IMPORTANT INFORMATION REGARDING PREPRINTS}

\begin{abstract}
a-Human Mutation is now publishing online preprints of accepted manuscripts prior to typesetting and page proof corrections. It is therefore crucial that you revise your manuscript carefully so that errors (typographical and grammatical) are corrected BEFORE the final accepted manuscript is posted online. The accepted preprint version will remain online until the corrected proofs are received and the typeset manuscript is finalized. At that time, the preprint version will be replaced with the final, typeset version online, in Early View.
\end{abstract}

\section{RESPONSE :}

We proofread the revised manuscript carefully, and no substantial changes carried out except for some minor style editing (e.g. abstract), and updating of citations and references (e.g. Rauch et al., 2010, De Luca et. al 2010).

\footnotetext{
b-It is essential that you submit a copyright transfer agreement (CTA) upon submission of your revised manuscript. This will avoid delay in publication of your article upon acceptance. If possible, the CTA must be signed by the corresponding author and should be signed by all contributing authors if practical. All authors must be made aware of the CTA and the rights it conveys to them.

The CTA can be found here:

wWw.wiley.com/go/ctaaus
} 
and must be filled out completely, including the article title and manuscript number. Please fax it to this number: (201) 748-6091.

\section{RESPONSE :}

A signed CTA has been prepared and will be faxed to the above indicated number, as soon as the revised manuscript has been uploaded. 


\title{
NKX2-5: An Update on this Hypermutable Homeodomain Protein and its Role in Human Congenital Heart Disease (CHD)
}

\author{
Stella Marie Reamon-Buettner and Juergen Borlak* \\ Molecular Medicine and Medical Biotechnology, Fraunhofer Institute of Toxicology and \\ Experimental Medicine, Nikolai-Fuchs-Strasse 1, D-30625 Hannover, Germany.
}

\author{
*Correspondence to Prof. Dr. Juergen Borlak, Molecular Medicine and Medical \\ Biotechnology, Fraunhofer Institute of Toxicology and Experimental Medicine, Nikolai- \\ Fuchs-Strasse 1, 30625 Hannover, Germany. \\ Tel: +49-511-5350-559; Fax +49-511-5350-573; E-mail: borlak@item.fraunhofer.de
}

Contract grant sponsors: Ministry of Science and Culture, Lower Saxony, Germany; Contract grant number: 25A.5-76251-99-3/00 


\begin{abstract}
Congenital heart disease (CHD) is among the most prevalent and fatal of all birth defects.

Deciphering its causes, however, is complicated as many patients affected by CHD have no family history of the disease. There is also widespread heterogeneity of cardiac malformations within affected individuals. Nonetheless, there have been tremendous efforts towards a better understanding of the molecular and cellular events leading to CHD. Notably, certain cardiacspecific transcription factors have been implicated in mammalian heart development and disruption of their activity in CHD; foremost is the homeodomain transcription factor NKX25. Indeed, more than 40 heterozygous $N K X 2-5$ germline mutations are spread along the coding region, many impact protein function. Thus, NKX2-5 appears to be hypermutable, yet the overall detection frequency in sporadic CHD is about $2 \%$ and NKX2-5 mutations are onetime detections with single-positives or private to families. Furthermore, there is lack of genotype-phenotype correlation, in which the same cardiac malformations have been exhibited in different $N K X 2-5$ mutations or the same $N K X 2-5$ mutation associated with diverse malformations. Here, we summarize published NKX2-5 germline mutations and explore different avenues in disease pathogenesis to support the notion of a multifactorial cause of CHD where possibly several genes and associated pathways are involved.
\end{abstract}

Keywords: heart development, congenital heart disease, cardiac malformations, transcription factors, $N K X 2-5$, mutations 


\section{Introduction}

Cardiac malformations in congenital heart disease (CHD) result from errors during heart development, a process which is very complex and completed in a relatively short period of time. Essentially within eight weeks of embryogenesis, the human heart undergoes several stages of development involving cardiac crescent formation, linear heart tube formation, cardiac looping, chamber formation and maturation, septation and valve formation. At the molecular and cellular levels, heart development entails precise orchestration of genetic events, as well as the interplay of master transcriptional regulators, signaling pathways and chromatin remodeling rendering the understanding of CHD a challenging task. But great efforts are underway towards the unravelling of mechanisms leading to CHD, as conveyed in recent reviews (Bruneau, 2008;Nemer, 2008;Joziasse et al., 2008;Bajolle et al., 2009;Leong et al., 2009;Combs and Yutzey, 2009). Notably, the pivotal role of certain transcription factors in heart development has been demonstrated, and gene targeting of cardiac-specific transcription factor genes in animal models especially in mice has provided valuable insights into heart anomalies (Nemer, 2008).

Over the years, family-based studies identified mutations in several genes controlling heart development, especially transcription factor genes (see reviews, Clark et al., 2006; Bruneau, 2008; Benson, 2010). Among these transcription factor genes with mutations associated with human CHD include NKX2-5 (MIM\# 600584), GATA4 (MIM\# $\underline{600576}$ ) and TBX5 (MIM\# 601620) and these mutations are often observed in patients with atrial, ventricular and atrioventricular septation defects. Although these family studies have been useful in uncovering genes linked to CHD, population-based studies show so far, rare detection of mutations in unrelated patients with CHD (e.g. Rajagopal et al., 2007;Posch et al., 2008); therefore, pointing to a multifactorial cause of disease. Furthermore, mutations exhibit variable expression, in which different cardiac malformations occur even from the same mutation, suggesting modifying factors and epigenetic effects contributing to disease 
manifestation. Indeed, a recent study which examined the effect of genetic background

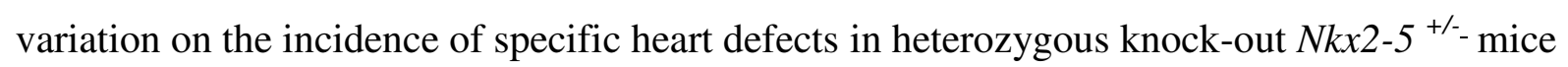
and in crosses to two different strains revealed that such genetic modifiers to play an important role in buffering cardiac developmental pathways against a major perturbation, while directing the manifestation of disease in a few (Winston et al., 2010).

In this paper, we will review efforts in identifying disease-associated mutations in the transcription factor gene $N K X 2-5$, and the clinical significance of such mutations in the pathogenesis of CHD. We summarize published germline NKX2-5 mutations and corresponding CHD phenotypes, their detection frequency, geographical location, as well as functional consequence as determined by assays or bioinformatic prediction. Finally, we explore different avenues in CHD pathogenesis, some of which challenge the well-accepted view of a single mutation as a direct cause of disease.

\section{NKX2-5 and its Role in Cardiac Development and Disease}

Nkx2-5 belongs to the NK-2 family of homeodomain-containing transcription factors, which are conserved in many organisms from flies to humans (Bartlett et al., 2010). Through the 60-amino-acid homeodomain (HD), Nkx2-5 interacts with DNA through a helix-turnhelix DNA-binding motif of three alpha helices, with helix 3 providing binding specificity. Important for Nkx2-5 function are also other conserved regions namely, the transactivation (TN) domain, and the NK2-specific domain (NK2-SD). Nkx2-5 is a transcriptional regulator during early embryonic heart development, and its absence in mice models results in embryonic lethality and arrested heart development at the looping stage (see reviews, Harvey et al., 2002;Akazawa and Komuro, 2005;Bartlett et al., 2010). Nkx2-5 is also essential for the formation, maturation and maintenance of the conduction system (Pashmforoush et al., 2004;Jay et al., 2004). Nkx2-5 regulates the number of cells in the cardiac conduction system in a dose-dependent manner (Jay et al., 2004). While null Nkx2-5 mice mutants appear to lack 
the primordium of the atrioventricular node, heterozygotes have half the number of cells. Anatomic hypoplasia of the conduction system may explain some of the defects in Nkx2-5 loss-of-function mutants. Notably, Nkx2-5 is expressed in both the first heart field (FHF) and the second heart field (SHF), the two distinct sources of cardiac progenitor cells contributing to different parts of the heart (Buckingham et al., 2005). This expression in progenitor cells indicates a higher role for $\mathrm{Nkx} 2-5$ in the hierarchy of transcriptional regulators of heart development.

Recent studies show further roles for Nkx2-5 in heart development and perinatal hearts. In mice, Nkx2-5 repression of Bmp2/Smad1 signaling regulates SHF proliferation and outflow tract (OFT) morphology (Prall et al., 2007). In the cardiac fields of Nkx2-5 mutants, genes controlling cardiac specification and maintenance of the progenitor state were upregulated, leading initially to progenitor overspecification, but subsequently to failed SHF proliferation and outflow tract (OFT) truncation. Nkx2-5-null embryos exhibited decrease in SHF proliferation, resulting in a smaller outflow tract and right ventricle. In vivo Cre-lox Pbased lineage tracing in mice showed that $\mathrm{Nkx} 2-5$-expressing cardiac progenitors contributed to the proepicardium (Zhou et al., 2008). Indeed, Nkx2-5 knockout resulted in abnormal proepicardial development, and decreased expression of the transcription factor Wilm's Tumor $1(\mathrm{Wt} 1)$, which in the heart its expression is confined to the proepicardium and epicardium. Furthermore, inhibiting the function of Nkx2-5 homologs (nkx2.5 and nkx2.7) in zebrafish showed their involvement in the regulation of heart tube extension as well as ventricular and atrial cell number (Targoff et al., 2008). The nkx-deficient heart tube failed to elongate normally: its ventricular portion was atypically short and wide, and its atrial portion was disorganized and sprawling. This atrial phenotype was associated with a surplus of atrial cardiomyocytes; ventricular cell number decreased in nkx-deficient embryos later in development, when cardiac chambers are emerging. 
Lastly, it has also been demonstrated using tamoxifen-inducible $N k x 2-5$ knockout mice that Nkx2-5 function is critical not only during cardiac development, but also in perinatal hearts, by regulating expression of several important gene products involved in conduction and contraction (Briggs et al., 2008). The perinatal loss of Nkx2-5 resulted in rapid conduction and contraction defects within 4 days after the deletion of $N k x 2-5$ alleles. Furthermore, using tamoxifen-inducible Cre transgene (Cre-ER), floxed-Nkx2-5 alleles were deleted beginning at 2 weeks of age (Takeda et al., 2009). The loss of Nkx2-5 beginning at 2 weeks of age also resulted in conduction and contraction defects, but disease progression was slower than in perinatal loss of Nkx2-5.

\section{An Update of $N K X 2-5$ Germline Mutations}

The human NKX2-5 gene maps to chromosome $5 \mathrm{q} 34$ and consists of two exons that encode a 324-amino-acid protein. Since the first report implicating NKX2-5 mutations in human CHD (Schott et al., 1998), the coding region of NKX2-5 has been consistently searched for additional disease-associated sequence alterations. There are at least 28 studies where germline NKX2-5 mutations have been analyzed or identified in CHD (Supp.Table S1). NKX2-5 mutations were identified in different countries, but majority were found in studies conducted in the United States and affect different regions of the gene (Supp. Figure S1, Supp. Table S2). Some mutations may appear though to cluster geographically, such as the three deletions from Japan, and the two substitutions from Germany (Supp. Figure S1).

At least 41 different NKX2-5 germline mutations, most of which lead to amino acid change (nonsynonymous mutations) have been reported (Figure 1, Supp. Table S2). Of these 41 mutations, 33 are single nucleotide substitutions, 6 deletions and 2 insertions. The NKX2-5 mutations are spread along the gene, and except for one at a splice site, all are located in the coding region. Mutations affect conserved regions, where 2 are in the TN domain, 14 in the homeodomain (HD), and 2 are in the NK2-SD domain. Only 5 of $41(12 \%)$ have been 
reported more than once in unrelated individuals, with c.73C $>\mathrm{T}$ (p.R25C) being frequently detected. However, p.R25C was also found in unaffected relatives and controls; hence, its pathogenicity remains unclear (Goldmuntz et al., 2001;Akcaboy et al., 2008; Esposito et al., 2009;Gioli-Pereira et al., 2010).

Furthermore, NKX2-5 mutations have been identified in both familial and sporadic cases of CHD, in which 25 of 41 are familial, 14 are sporadic, and 2 are sporadic/familial cases (Figure 1, Supp. Table S2). Patients are heterozygous for the NKX2-5 mutations, and frequent CHD malformations in patients with $N K X 2-5$ mutations are atrial septal defect (ASD) with or without atrioventricular block (AV) block. Specifically, 29 of 41 mutations were identified in patients with ASD II, 26 in AV block, and 25 in combined ASD II and AV block. Other CHD phenotypes were also found including Tetralogy of Fallot (TOF) in 7 mutations, as well as ventricular septal defect (VSD) in 9 mutations. A quick characterization of the 41 NKX2-5 mutations identified in patients with CHD is depicted in Figure 2.

\section{Functional Significance of $N K X 2-5$ Mutations}

Of the 40 mutations identified in the coding region of NKX2-5, 25 are missense, 7 nonsense, 7 frameshift and 1 leading to an amino acid deletion. Most of these would affect protein function as predicted by bioinformatic methods or by functional assays (Table 1). So far, only 4 mutations have been predicted to have no deleterious effects on protein function. Specifically, 17 mutations would lead to a truncated protein in which 11 affect both the homeodomain and NK2-SD. Notably, certain mutations that are not outright nonsense in the homeodomain would result in the breakage of the secondary structure (Figure 3) and /or affect highly conserved residues (Figure 4). Moreover, 16 mutations exhibited impaired function in all or any of the assays particularly DNA binding, transactivation activity, protein-protein interaction and nuclear localization (Table 1, Supp. Table S3). Essentially, NKX2-5 mutations 
affecting the homeodomain resulted in reduced or loss of DNA binding, transactivation activities, and protein-protein interactions particularly with GATA4 and TBX5 (Kasahara et al., 2000;Kasahara and Benson, 2004;Zhu et al., 2000;Monzen et al., 2002;Inga et al., 2005;Esposito et al., 2009).

\section{Lack of Genotype-Phenotype Correlation}

Despite $N K X 2-5$ hypermutability and the pathogenic potentials of $N K X 2-5$ germline mutations, there is lack of genotype-phenotype correlation of NKX2-5 mutations in CHD (see also review, Benson, 2010). Notably, the detection frequency of $N K X 2-5$ mutations in sporadic cases of CHD is about $2 \%$ and in several studies none was found (Table 2). Most of the identified NKX2-5 mutations are unique and diverse cardiac malformations have been associated with NKX2-5 mutations (Figure 1). Furthermore, same CHD phenotypes have been exhibited by patients with different $N K X 2-5$ mutations or same $N K X 2-5$ mutation gave different CHD phenotypes in regards to severity even within families (see for instance, Figure 1 and Supp. Table S2). Indeed, more than half of identified NKX2-5 mutations are familial cases, and families have their private mutations.

Even as new studies on NKX2-5 mutations keep coming in, the picture remains basically unchanged. After genetic analysis of NKX2-5 mutations in 230 patients with TOF, a detection frequency of $0.9 \%$ was obtained (Rauch et al., 2010). Two patients with nonsyndromic TOF harbored an unknown variant each (i.e. p.C270Y and p.V315L), both located at the carboxy terminal and which did not show an effect on the transcriptional reporter assay used. The most frequent variant p.R25C was also detected in two patients. In another study, no NKX2-5 mutations were found in 96 patients with idiopathic atrial fibrillation, a condition of arrhythmia but no visible structural defects (Boldt et al., 2009). After sequencing NKX2-5 in 34 patients with stroke and patent foramen ovale (PFO), no pathogenic mutations were obtained (Belvis et al., 2009). All the while, NKX2-5 mutations are not exclusive to CHD. 
Indeed, NKX2-5 mutations (p.A119S, p.R25C, p.R161P) were found in thyroid dysgenesis, in patients with or without cardiac anomalies (Dentice et al., 2006), suggesting a broader role for NKX2-5 in organogenesis and pathophysiology.

There are several factors that may contribute to this lack of genotype-phenotype correlation. For one, genetic background can modify the phenotypic expression of single gene mutations in mice and humans (Rajagopal et al., 2007). Indeed, modifier genes have been shown to affect NKX2-5 mutations in the pathogenesis of CHD (Kaiser et al., 2005; Winston et al., 2010). There is also the possible influence of synonymous (silent) mutations and dbSNPs affecting protein expression and function (Sauna et al., 2007). Such silent variants and dbSNPs eventually serve as risk factors for CHD. Furthermore, buffering that can result from compensation by a normally functioning second allele or a duplicated gene or a pathway that maintains residual function may also explain reduced penetrance of mutations in sporadic cases of CHD (see review, Bentham and Bhattacharya, 2008). These authors proposed that the genetic architecture of sporadic CHD likely includes accumulation of rare nonsynonymous variants in cardiac developmental genes leading to mutational loading of cardiac developmental networks, copy number variation in cardiac developmental genes, and common variants that may not be obviously linked to cardiac development but may alter genetic buffering pathways. Moreover, as one review commented (Weismann and Gelb, 2007), germline mutations may not be compatible with survival of the developing embryo because many of the genes that control cardiac development also play critical roles in the development of other organ systems and in any case, would not likely cause CHD only. Summing up, a single germline NKX2-5 mutation as the direct cause of disease or a simple Mendelian inheritance alone may not sufficiently explain disease pathogenesis. Needless to say, none of the patients studied so far are homozygous for NKX2-5 variant alleles. 


\section{Molecular Basis of CHD Pathogenesis}

The landscape for CHD pathogenesis is complex. First of all, majority of CHD cases are sporadic in which patients have no family history of the disease. Indeed, the contribution of family history of any CHD among first-degree relatives to the overall prevalence of CHD is small, approximately 2-4\% (Oyen et al., 2009). There is clinical or phenotype heterogeneity within affected individuals, as well as within and between families. Disease association is difficult owing to lack of clear genotype-phenotype correlation of mutations. For instance, patients harboring the same $N K X 2-5$ mutation have different malformations; or mutations in different genes give the same disease phenotype. Specifically, common cardiac malformations associated with NKX2-5 mutations are AV block, ASD, and VSD. But the same structural anomalies are also observed in mutations in other transcription factor genes (see reviews, Clark et al., 2006;Nemer, 2008). ASD is associated with mutations involving GATA4, TBX5 and ZIC3; AV block in NKX2-5 and TBX5; or VSD in GATA4 and TBX5. Thus, CHD is considered as a multifactorial disease, likely resulting from gene-environment interactions which eventually determine disease penetrance and expressivity. Among the environmental risk factors for CHD are chemicals, drugs, infections, and maternal diseases (reviewed in Jenkins et al., 2007).

At the molecular and cellular levels, heart development can practically go wrong in many directions leading to diverse cardiac malformations observed in CHD. Notably, heart development requires spatial and timely interactions of different transcription factors to regulate downstream targets, and breakdown of transcriptional interactions can lead to various CHD phenotypes (see reviews, Nemer, 2008;Bruneau, 2008). For example, Nkx2-5 through the homeodomain interacts physically and synergistically with Gata4 and Tbx5, such that abrogation of their interaction leads to CHD. Indeed, NKX2-5 mutations identified in patients affecting the homeodomain have been demonstrated to result in reduced interaction with Gata4 and Tbx5 (Kasahara and Benson, 2004). Recently, it has been shown that Nkx2-5 can 
directly interact with Mef2c, and the physical, functional, and genetic interactions between Nkx2-5 and Mef2c are necessary for ventricle formation (Vincentz et al., 2008). While individual mutants for both Nkx2-5 and Mef2c had identifiable ventricles, double mutants displayed ventricular hypoplasia, a more severe cardiac phenotype. Besides transcription factors, Nkx2-5 can also interact with a histone methyltransferase to regulate target genes. A recent study linked Nkx2-5 to Wolf-Hirschhorn syndrome (MIM \#194190) where cardiac septal defects are among the anomalies, through an association with Whsc1, an H3K36me3specific histone methyltransferase in mouse embryonic hearts (Nimura et al., 2009). The effects of Whscl haploinsufficiency increased in heterozygous Nkx2-5 mutant hearts, and reporter assays showed that Whsc1 negatively modulated the transcriptional activity of Nkx25 .

A complex network of signaling molecules and their signal transduction pathways participates in the precise orchestration of the many morphogenetic events in heart development especially in the specification, proliferation and differentiation of cardiac progenitor cells (reviewed in Wagner and Siddiqui, 2007a;Wagner and Siddiqui, 2007b;Niessen and Karsan, 2008;Nemir and Pedrazzini, 2008;Rochais et al., 2009). Shown to regulate cardiogenesis include bone morphogenetic proteins (BMP), fibroblast growth factors (FGF), Wnt, Hedgehog, Nodal, retinoic acid, neuregulin, vascular endothelial growth factor (VEGF) and Notch signaling pathways. Errors in these signaling pathways can impair heart development. For instance, mutations in the Notch signaling pathway (McBride et al., 2008) or in the Nodal signaling pathway (Roessler, 2008) have been identified in patients with various cardiac anomalies.

Furthermore, there are now studies showing that defects in chromatin remodeling can lead to CHD. Chromatin remodeling allows transcriptional machinery access to gene regulatory elements and is essential in heart development. Silencing of Smarcd3, which encodes Baf60c, a subunit of the Brg1-associated-factor (BAF) chromatin remodeling 
complex, caused in ES-cell-derived mouse embryos severe cardiac malformations including hypoplastic atrium, hypoplastic right ventricle, single ventricle, abnormal outflow tract and severely impaired trabecular formation (Lickert et al., 2004). Furthermore, Baf180, a specific subunit of the PBAF form of the BAF complex is required for cardiac and placental development (Wang et al., 2004). Ablation of Baf180 in mouse embryos resulted in severe hypoplastic ventricle, ventricular septal defect and trophoblast placental defects. Recently, it has been shown that myocardial trabeculation requires Brg1, a chromatin remodeling protein, (Stankunas et al., 2008a). Trabeculation defects occurred in the absence of endocardial Brg1 which resulted from the derepression of a secreted matrix metalloproteinase, ADAMTS1, which normally only increases in expression later in development to prevent excessive trabeculation.

Thus, there is justification for proposing the concept of one heart disease-several mechanisms-several genes to explain the heterogeneity of certain cardiac malformations, which is not by chance but by the heterogeneity of mechanisms (Bajolle et al., 2009). According to this concept, a certain malformation may originate from different embryology mechanisms, which in turn controlled by multiple genes. Given as example is common arterial trunk (CAT), which may result from a participation defect of progenitors from the second cardiac field and/or a migration defect of the neural crest cells and/or a rotation defect of the myocardium and/or a formation abnormality of the endocardial cushions. Further example is atrioventricular valve formation which is regulated by different genetic pathways (Joziasse et al., 2008). Disturbances in each subset of a particular pathway, i.e. ligand receptor, transcription factor or extracellular matric proteins can all result in similar cardiac defects.

Recently, a study showed that interactions between alleles of three $P b x$ genes, which encode homeodomain transcription factors, are sufficient to determine the phenotypic presentation of CHD in mice (Stankunas et al., 2008b). A major role is served by Pbxl, whose 
inactivation results in persistent truncus arteriosus (PTA). Reduction or absence of $P b x 2$ or $P b x 3$ leads to $P b x l$ haploinsufficiency and specific malformations that resemble Tetralogy of Fallot, overriding aorta with ventricular septal defect, and bicuspid aortic valves. Disruption of Meis1, which encodes a Pbx DNA-binding partner, results in cardiac anomalies that resemble those caused by $P b x$ mutations. Altogether, these findings among others challenge the well-accepted paradigm in autosomal dominant monogenic disease that 1 mutation in a single gene as the direct cause of disease, and have major implication in clinical evaluation, diagnosis, and management of families with a genetic cardiovascular disease (see for instance, Kelly and Semsarian, 2009).

\section{Learning from the Leipzig Collection of Malformed Hearts}

Model organisms especially mice provide insights into the molecular mechanisms leading to CHD. But results can be species-specific and only a minority of mutations in these genes have been related to CHD in humans (see Bruneau, 2008). Furthermore, genetic studies on CHD are usually based on blood samples and such analysis may not reveal complete genetic alterations leading to the disease. To gain insights into the molecular causes of CHD, we conducted in the past genetic analysis of NKX2-5 and other cardiac-specific transcription factor genes, most recently on HAND1 (MIM\# 602406), in a rare collection of morphologically, well-characterized explanted, malformed hearts stored in formalin for many years (Reamon Buettner and Borlak, 2004; Reamon-Buettner et al., 2004; 2008; 2009). This research identified somatic mutations of cardiac-specific transcription factor genes as a possible disease-causing mechanism as discussed below.

Direct sequencing of different cardiac-specific transcription factor genes in 'affected' tissues of malformed hearts revealed frequent disease-associated mutations which were mainly absent in 'unaffected' tissues in the same patient's heart. This finding indicates somatic mosaicism and somatic origin of mutations. Many patients displayed multiple deleterious 
mutations not only in one but several transcription factor genes. While for some investigators in the field, it would be easiest to explain the findings from the Leipzig heart collection as artifacts on the basis of degraded DNA owing to many years of storage in formalin solution (Draus et al., 2009), the study on such a rare collection of malformed hearts may lead to important insights on heart development and CHD. Here are some of the pros and cons of the scientific discussion.

\section{Somatic mutations as a molecular rationale for $\mathrm{CHD}$}

Somatic mutations may result from environmental insults and epigenetic instability to provide a molecular rationale for CHD. Although somatic mutations are well known in cancer, they can also occur in non-cancer diseases. For example, somatic mutations in the gene TEK encoding the endothelial cell tyrosine kinase receptor TIE2 were identified in lesions from patients with sporadic venous malformations (Limaye et al., 2009). The somatic mutations included a frequent p.L914F substitution and several double mutations in cis, all of which resulted in ligand-independent TIE2 hyperphosphorylation in vitro. Somatic mutations were also identified in GJA5 gene encoding cardiac gap-junction protein connexin 40 in cardiac tissues of patients with atrial fibrillation (Gollob et al., 2006). Atrial fibrillation is the most common type of cardiac arrhythmia and a leading cause of cardiovascular morbidity, particularly stroke.

\section{Multiple mutations in complex cardiac malformations}

The presence of multiple mutations in patients with complex heart malformations may be a reflection of disease severity. Indeed, there are now studies to show that the presence of multiple disease-causing mutations in the same gene or in different genes can be an indication of disease severity (Kelly and Semsarian, 2009). In familial hypertrophic cardiomyopathy (FHC) which is characterized by genetic and clinical heterogeneity, patients with two FHCcausing mutations typically had more severe phenotype (i.e. earlier onset of disease, greater left ventricular hypertrophy and a higher incidence of sudden cardiac death events) compared 
with carriers of single mutation (Tsoutsman et al., 2008a; Tsoutsman et al., 2008b).

Furthermore, in familial transposition of great arteries (TGA) some patients harbored more than one mutation in laterality genes which presumably influenced cardiac phenotype (De Luca et al., 2010).

\section{A structural malformation may result from combined effects of deleterious mutations in}

\section{several transcription factor genes}

Certain malformations may have resulted from combined effects of deleterious mutations in several transcription factor genes. In the hypoplastic hearts group, a frameshift mutation p.A126fs (HAND1) was frequently detected in hypoplastic ventricles (ReamonBuettner et. al., 2008). But further analysis led to the detection of additional loss-of-function mutations affecting the 2nd zinc finger of GATA4 and homeodomain of NKX2-5 (unpublished results). For example, in the hypoplastic left ventricle of patient A82, we detected in HAND1 p.A126fs; in GATA4 p.R266X; and in NKX2-5 homozygous for p.L116P, p.T178M, p.K192T.

\section{Indications of transient hypermutability/genetic instability in cardiac tissues of CHD patients}

Hypermutability varied among the different transcription factor genes, but mutations were non-random and closely-spaced. The multiple mutations observed in the affected tissues were possibly the result of various haplotypes. Specifically, depending on the stretch of DNA being analyzed, the closely-spaced sequence alterations could involve those in the coding or non-coding regions, and when in the coding region, mutations could be synonymous or nonsynonymous. For example, in two patients affected by VSD, we found 11 non-random, closely-spaced mutations in NKX2-5 within 362-bp spanning intronic and coding sequences of exon 2. In this window, the separation of an NKX2-5 mutation to the next ranged from 3 bp to $121 \mathrm{bp}$, but majority was less than $30 \mathrm{bp}$. Moreover, after cloning of a PCR fragment 'heterozygous' for the multiple mutations in an analyzed transcription factor gene, more than 
the two expected haplotypes or alleles were found. In some cases, all the variants occurred in cis. The occurrence of closely-spaced multiple mutations in human genes has been suggested to be possible signatures of transient hypermutability, a mutational mechanism with the potential to generate multiple synchronous mutations, resulting from a perturbation of one of the many transactions that maintain genetic stability (Chen et al., 2009). Specifically, transient hypermutability may result from (1) the deregulated expression of, or conformational change in, either a replicative DNA polymerase or another protein involved in the maintenance of replication fidelity; (2) the disruption of the balance of the nucleotide pool; or (3) the recruitment of error-prone DNA polymerases in DNA replication or repair (reviewed in Chen et al., 2009).

\section{Future Directions}

Understanding the molecular process leading to CHD should provide important insights into the etiology and treatment of patients. This is a difficult task as CHD is complex entailing defects in multiple genes and different pathways. A good grasp of CHD would thus require a whole-genome functional approach, in which for a specific structural defect a combination of different genes and associated pathways involving transcriptional machinery, signal transduction, and chromatin remodeling will be simultaneously interrogated. But with high-throughput technologies in different 'omics' available, as well as accumulating evidence from animal models, this may be no longer a monumental undertaking. Eventually, there is the task ahead to translate discoveries to human CHD, although in future genetic studies corresponding molecular events may have been identified by then to explain genetic heterogeneity, reduced penetrance and variable expressivity owing to complex inheritance of the disease. Nevertheless, there is also a need to better understand environmental factors that possibly cause $\mathrm{CHD}$, such as intrauterine stress shortly after conception owing to environmental contaminants. Indeed, there is evidence that in utero DNA damage from 
environmental pollution is associated with somatic gene mutation in newborns (Perera et al., 2002), and that there are indications for increased risk of CHD in polluted areas (Brook et al., 2004). Additional research areas should be addressed:

1. To gain deeper knowledge of how epigenetic regulation influence molecular mechanisms of heart development and its disruptions in CHD. Epigenetics describes heritable changes in gene expression that are not coded in the DNA sequence, but an interplay of DNA methylation, histone modifications and expression of non-coding RNAs, in the regulation of gene expression patterns. Epigenetic mechanisms are essential for development and differentiation, but they can become misdirected leading to birth malformations and various human diseases. Indeed, efforts are now underway in this direction, where for instance, deletion of miRNAs in mice during cardiogenesis has been shown to result in double-outlet right ventricle with a concurrent ventricular septal defect (Saxena and Tabin, 2010).

2. To decipher mechanisms of chromatin remodeling and DNA repair in heart development and CHD. Essentially, DNA is packaged, through histone and non-histone proteins, into a condensed structure termed chromatin. The nucleosome is the basic repeating unit of chromatin, consisting of about 147-bp of DNA wrapped approximately two times around a histone core comprising two copies of each of the histone proteins $\mathrm{H} 2 \mathrm{~A}, \mathrm{H} 2 \mathrm{~B}, \mathrm{H} 3$ and $\mathrm{H} 4$. Through chromatin remodeling, histone-DNA is disrupted resulting in a 'relaxed' chromatin, which then allows transcriptional machinery contact DNA to turn genes 'on' or 'off'. But more important, chromatin remodeling also facilitates DNA-damage-response proteins access DNA lesions and eventually initiate repair to maintain genome integrity (for reviews, Osley and Shen, 2006; Osley et al., 2007). Chromatin remodeling factors may involve those modifying enzymes that catalyze post-translational modifications of residues on both histone core and tails; or those enzymes that use ATP hydrolysis to disrupt histone-DNA leading to structurally 
altered nucleosomes, or to sliding or eviction of nucleosomes. Although there are now studies showing an essential role of chromatin remodeling with respect to transcriptional regulation in heart development and CHD (Lickert et al., 2004; Wang et al., 2004), none has been found so far on DNA repair. The role of DNA repair would be of utmost importance during early heart development, notably in embryonic cells and committed precursors of the mesoderm.

3. To identify molecular causes of hypermutability of genes and subsequent contribution to CHD, and explore whether activation-induced cytidine deaminase (AID) causes somatic hypermutability of cardiogenic genes in CHD. AID is a master regulator of diversification of antibody genes by initiating the processes of somatic hypermutation (SHM), gene conversion (IGC), and class-switch recombination (CSR) in B-lymphocytes (see reviews, Teng and Papavasiliou, 2007;Liu and Schatz, 2009). Essentially, AID induces somatic hypermutability of immunoglobulin $(I g)$ genes by cytosine deamination resulting in the generation of a uracil and thus converting a $\mathrm{C}: \mathrm{G}$ basepair into a $\mathrm{U}: \mathrm{G}$ mismatch, which is then processed into a mutation by different mechanisms. For instance, DNA replication over the uracil leads to $\mathrm{C}$ to T or G to A transition mutations. Alternatively, removal of the uracil by uracil-DNA glycosylase (UNG) generates an abasic site in the DNA, which when replicated across yields transition and transversion mutations at the $\mathrm{C}: \mathrm{G}$ basepair. The $\mathrm{U}: \mathrm{G}$ mismatch can also be recognized by the mismatched repair factors allowing the generation of either mutations at A:T basepairs by error prone patch repair or a nicked DNA recombination substrate. However, there are now evidences for AID to deaminate not only Ig genes, but many more genes including numerous oncogenes implicated in B-cell tumorigenesis (Liu and Schatz, 2009). Indeed, AID can be potentially functional in a variety mammalian of non-B cells triggering genome-wide hypermutation and consequently to genetic instability and neoplasm (Perez-Duran et al., 2007). 


\section{ACKNOWLEDGEMENTS}

We thank the Institute of Anatomy, University of Leipzig for providing the heart collection; to

Dr. Mike Resnick and Dr. Alberto Inga for the fruitful discussions; and A. Roskowetz and A.

Hiemisch, for the excellent technical support. The financial support of the Lower Saxony

Ministry of Science and Culture, Germany to JB is greatly appreciated. 


\section{References}

Akazawa H, Komuro I. 2005. Cardiac transcription factor Csx/Nkx2-5: Its role in cardiac development and diseases. Pharmacol Ther 107: 252-268.

Akcaboy MI, Cengiz FB, Inceoglu B, Ucar T, Atalay S, Tutar E, Tekin M. 2008. The effect of p.Arg25Cys alteration in NKX2-5 on conotruncal heart anomalies: mutation or polymorphism? Pediatr Cardiol 29: 126-129.

Bajolle F, Zaffran S, Bonnet D. 2009. Genetics and embryological mechanisms of congenital heart disease. Arch Cardiovasc Dis 102: 59-63.

Bartlett H, Veenstra GJ, Weeks DL. 2010. Examining the cardiac NK-2 genes in early heart development. Pediatr Cardiol 31:335-341.

Belvis R, Tizzano EF, Marti-Fabregas J, Leta RG, Baena M, Carreras F, Pons-Llado G, Baiget M, and Marti-Vilalta JL. 2009. Mutations in the NKX2-5 gene in patients with stroke and patent foramen ovale. Clin Neurol Neurosurg 111: 574-578.

Benson DW. 2010. Genetic origins of pediatric heart disease. Pediatr Cardiol 31: 422-429.

Benson DW, Silberbach GM, Kavanaugh-McHugh A, Cottrill C, Zhang Y, Riggs S, Smalls O, Johnson MC, Watson MS, Seidman JG, Seidman CE, Plowden J, Kugler JD. 1999. Mutations in the cardiac transcription factor NKX2.5 affect diverse cardiac developmental pathways. J Clin Invest 104: 1567-1573.

Bentham J, Bhattacharya S. 2008. Genetic mechanisms controlling cardiovascular development. Ann N Y Acad Sci 1123: 10-19.

Bjornstad PG, Leren TP. 2009. Familial atrial septal defect in the oval fossa with progressive prolongation of the atrioventricular conduction caused by mutations in the NKX2.5 gene. Cardiol Young 19: 40-44.

Boldt LH, Posch MG, Perrot A, Polotzki M, Rolf S, Parwani AS, Huemer M, Wutzler A, Ozcelik C, Haverkamp W. 2009. Mutational analysis of the PITX2 and NKX2-5 genes in patients with idiopathic atrial fibrillation. Int J Cardiol. Epub ahead of print 
(doi:10.1016/j.ijcard.2009.11.023).

Briggs LE, Takeda M, Cuadra AE, Wakimoto H, Marks MH, Walker AJ, Seki T, Oh SP, Lu JT, Sumners C, Raizada MK, Horikoshi N, Weinberg EO, Yasui K, Ikeda Y, Chien KR, Kasahara H. 2008. Perinatal loss of Nkx2-5 results in rapid conduction and contraction defects. Circ Res 103: 580-590.

Brook RD, Franklin B, Cascio W, Hong Y, Howard G, Lipsett M, Luepker R, Mittleman M, Samet J, Smith SC, Jr., Tager I. 2004. Air pollution and cardiovascular disease: a statement for healthcare professionals from the Expert Panel on Population and Prevention Science of the American Heart Association. Circulation 109: 2655-2671.

Bruneau BG. 2008. The developmental genetics of congenital heart disease. Nature 451: 943948.

Buckingham M, Meilhac S, Zaffran S. 2005. Building the mammalian heart from two sources of myocardial cells. Nat Rev Genet 6: 826-835.

Chen JM, Ferec C, Cooper DN. 2009. Closely-spaced multiple mutations as potential signatures of transient hypermutability in human genes. Hum Mutat 30: 1435-1448.

Clark KL, Yutzey KE, Benson DW. 2006. Transcription factors and congenital heart defects. Annu Rev Physiol 68: 97-121.

Combs MD, Yutzey KE. 2009. Heart valve development: regulatory networks in development and disease. Circ Res 105: 408-421.

De Luca A, Sarkozy A, Consoli F, Ferese R, Guida V, Dentici ML, Mingarelli R, Bellacchio E, Tuo G, Limongelli G, Digilio MC, Marino B, Dallapiccola B. 2010. Familial transposition of great arteries caused by multiple mutations in laterality genes. Heart 96:673-677.

Dentice M, Cordeddu V, Rosica A, Ferrara AM, Santarpia L, Salvatore D, Chiovato L, Perri A, Moschini L, Fazzini C, Olivieri A, Costa P, Stoppioni V, Baserga M, De Felice M, Sorcini M, Fenzi G, Di Lauro R, Tartaglia M, Macchia PE. 2006. Missense mutation in the 
transcription factor NKX2-5: a novel molecular event in the pathogenesis of thyroid dysgenesis. J Clin Endocrinol Metab 91: 1428-1433.

Draus JM, Jr., Hauck MA, Goetsch M, Austin EH, III, Tomita-Mitchell A, Mitchell ME. 2009. Investigation of somatic NKX2-5 mutations in congenital heart disease. J Med Genet 46: $115-122$.

Elliott DA, Kirk EP, Yeoh T, Chandar S, McKenzie F, Taylor P, Grossfeld P, Fatkin D, Jones O, Hayes P, Feneley M, Harvey RP. 2003. Cardiac homeobox gene NKX2-5 mutations and congenital heart disease: associations with atrial septal defect and hypoplastic left heart syndrome. J Am Coll Cardiol 41: 2072-2076.

Esposito G, Grutter G, Drago F, Costa MW, De Santis A, Bosco G, Marino B, Bellacchio E, Lepri F, Harvey RP, Sarkozy A, Dallapiccola B. 2009. Molecular analysis of PRKAG2, LAMP2, and NKX2-5 genes in a cohort of 125 patients with accessory atrioventricular connection. Am J Med Genet A 149A: 1574-1577.

Gioli-Pereira L, Pereira AC, Mesquita SM, Xavier-Neto J, Lopes AA, Krieger JE. 2010. NKX2.5 mutations in patients with non-syndromic congenital heart disease. Int J Cardiol $138: 261-265$.

Goldmuntz E, Geiger E, Benson DW. 2001. NKX2.5 mutations in patients with tetralogy of fallot. Circulation 104: 2565-2568.

Gollob MH, Jones DL, Krahn AD, Danis L, Gong XQ, Shao Q, Liu X, Veinot JP, Tang AS, Stewart AF, Tesson F, Klein GJ, Yee R, Skanes AC, Guiraudon GM, Ebihara L, Bai D. 2006. Somatic mutations in the connexin 40 gene (GJA5) in atrial fibrillation. N Engl J Med 354: 2677-2688.

Gutierrez-Roelens I, De Roy L, Ovaert C, Sluysmans T, Devriendt K, Brunner HG, Vikkula M. 2006. A novel CSX/NKX2-5 mutation causes autosomal-dominant AV block: are atrial fibrillation and syncopes part of the phenotype? Eur J Hum Genet 14: 1313-1316. 
Gutierrez-Roelens I, Sluysmans T, Gewillig M, Devriendt K, Vikkula M. 2002. Progressive AV-block and anomalous venous return among cardiac anomalies associated with two novel missense mutations in the CSX/NKX2- 5 Gene. Hum Mutat 20: 75-76.

Hamanoue H, Rahayuningsih SE, Hirahara Y, Itoh J, Yokoyama U, Mizuguchi T, Saitsu H, Miyake N, Hirahara F, Matsumoto N. 2009. Genetic screening of 104 patients with congenitally malformed hearts revealed a fresh mutation of GATA4 in those with atrial septal defects. Cardiol Young 19: 482-485.

Harvey RP, Lai D, Elliott D, Biben C, Solloway M, Prall O, Stennard F, Schindeler A, Groves N, Lavulo L, Hyun C, Yeoh T, Costa M, Furtado M, Kirk E. 2002. Homeodomain factor Nkx2-5 in heart development and disease. Cold Spring Harb Symp Quant Biol 67: 107-114. Hirayama-Yamada K, Kamisago M, Akimoto K, Aotsuka H, Nakamura Y, Tomita H, Furutani M, Imamura S, Takao A, Nakazawa M, Matsuoka R. 2005. Phenotypes with GATA4 or NKX2.5 mutations in familial atrial septal defect. Am J Med Genet A 135: 4752.

Hobbs CA, Cleves MA, Keith C, Ghaffar S, James SJ. 2005. NKX2.5 and congenital heart defects: A population-based study. Am J Med Genet A 134: 223-225.

Hosoda T, Komuro I, Shiojima I, Hiroi Y, Harada M, Murakawa Y, Hirata Y, Yazaki Y. 1999. Familial atrial septal defect and atrioventricular conduction disturbance associated with a point mutation in the cardiac homeobox gene CSX/NKX2-5 in a Japanese patient. Jpn Circ J 63: 425-426.

Ikeda Y, Hiroi Y, Hosoda T, Utsunomiya T, Matsuo S, Ito T, Inoue J, Sumiyoshi T, Takano H, Nagai R, Komuro I. 2002. Novel point mutation in the cardiac transcription factor CSX/NKX2.5 associated with congenital heart disease. Circ J 66: 561-563.

Inga A, Reamon-Buettner SM, Borlak J, Resnick MA. 2005. Functional dissection of sequence-specific NKX2-5 DNA binding domain mutations associated with human heart septation defects using a yeast-based system. Hum Mol Genet 14: 1965-1975. 
Jay PY, Harris BS, Maguire CT, Buerger A, Wakimoto H, Tanaka M, Kupershmidt S, Roden DM, Schultheiss TM, O'Brien TX, Gourdie RG, Berul CI, Izumo S. 2004. Nkx2-5 mutation causes anatomic hypoplasia of the cardiac conduction system. J Clin Invest 113: 11301137.

Jenkins KJ, Correa A, Feinstein JA, Botto L, Britt AE, Daniels SR, Elixson M, Warnes CA, Webb CL. 2007. Noninherited risk factors and congenital cardiovascular defects: current knowledge: a scientific statement from the American Heart Association Council on Cardiovascular Disease in the Young: endorsed by the American Academy of Pediatrics. Circulation 115: 2995-3014.

Joziasse IC, van de Smagt JJ, Smith K, Bakkers J, Sieswerda GJ, Mulder BJ, Doevendans PA. 2008. Genes in congenital heart disease: atrioventricular valve formation. Basic Res Cardiol 103: 216-227.

Kaiser K, Takematsu M, Jay PY. 2005. Modifier genes in the pathogenesis of congenital heart disease. Pediatr Res 58: 818.

Kasahara H, Benson DW. 2004. Biochemical analyses of eight NKX2.5 homeodomain missense mutations causing atrioventricular block and cardiac anomalies. Cardiovasc Res 64: $40-51$.

Kasahara H, Lee B, Schott JJ, Benson DW, Seidman JG, Seidman CE, Izumo S. 2000. Loss of function and inhibitory effects of human CSX/NKX2.5 homeoprotein mutations associated with congenital heart disease. J Clin Invest 106: 299-308.

Kelly M, Semsarian M. 2009. Multiple mutations in genetic cardiovascular disease: a marker of disease severity? Circ Cardiovasc Genet 2: 182-190.

Khetyar M, Tinworth L, Syrris P, Abushaban L, Abdulazzaq Y, Silengo M, Carvalho J, Carter N. 2008. NKX2.5/NKX2.6 mutations are not a common cause of isolated type 1 truncus arteriosus in a small cohort of multiethnic cases. Genet Test 12: 467-469. 
Konig K, Will JC, Berger F, Muller D, Benson DW. 2006. Familial congenital heart disease, progressive atrioventricular block and the cardiac homeobox transcription factor gene NKX2.5: identification of a novel mutation. Clin Res Cardiol 95: 499-503.

Leong FT, Freeman LJ, Keavney BD. 2009. Fresh fields and pathways new: recent genetic insights into cardiac malformation. Heart 95: 442-447.

Lickert H, Takeuchi JK, von B, I, Walls JR, McAuliffe F, Adamson SL, Henkelman RM, Wrana JL, Rossant J, Bruneau BG. 2004. Baf60c is essential for function of BAF chromatin remodelling complexes in heart development. Nature 432: 107-112.

Limaye N, Wouters V, Uebelhoer M, Tuominen M, Wirkkala R, Mulliken JB, Eklund L, Boon LM, Vikkula M. 2009. Somatic mutations in angiopoietin receptor gene TEK cause solitary and multiple sporadic venous malformations. Nat Genet 41: 118-124.

Liu M, Schatz DG. 2009. Balancing AID and DNA repair during somatic hypermutation. Trends Immunol 30: 173-181.

Majumdar R, Yagubyan M, Sarkar G, Bolander ME, Sundt TM, III. 2006. Bicuspid aortic valve and ascending aortic aneurysm are not associated with germline or somatic homeobox NKX2-5 gene polymorphism in 19 patients. J Thorac Cardiovasc Surg 131: $1301-1305$.

McBride KL, Riley MF, Zender GA, Fitzgerald-Butt SM, Towbin JA, Belmont JW, Cole SE. 2008. NOTCH1 mutations in individuals with left ventricular outflow tract malformations reduce ligand-induced signaling. Hum Mol Genet 17: 2886-2893.

McElhinney DB, Geiger E, Blinder J, Woodrow BD, Goldmuntz E. 2003. NKX2.5 mutations in patients with congenital heart disease. J Am Coll Cardiol 42: 1650-1655.

Monzen K, Zhu W, Kasai H, Hiroi Y, Hosoda T, Akazawa H, Zou Y, Hayashi D, Yamazaki T, Nagai R, Komuro I. 2002. Dual effects of the homeobox transcription factor Csx/Nkx2-5 on cardiomyocytes. Biochem Biophys Res Commun 298: 493-500. 
Nemer M. 2008. Genetic insights into normal and abnormal heart development. Cardiovasc Pathol 17: 48-54.

Nemir M, Pedrazzini T. 2008. Functional role of Notch signaling in the developing and postnatal heart. J Mol Cell Cardiol 45: 495-504.

Niessen K, Karsan A. 2008. Notch signaling in cardiac development. Circ Res 102: 11691181.

Nimura K, Ura K, Shiratori H, Ikawa M, Okabe M, Schwartz RJ, Kaneda Y. 2009. A histone H3 lysine 36 trimethyltransferase links Nkx2-5 to Wolf-Hirschhorn syndrome. Nature 460: 287-291.

Osley MA, Shen X. 2006. Altering nucleosomes during DNA double-strand break repair in yeast. Trends Genet 22: 671-677.

Osley MA, Tsukuda T, Nickoloff JA. 2007. ATP-dependent chromatin remodeling factors and DNA damage repair. Mutat Res 618: 65-80.

Oyen N, Poulsen G, Boyd HA, Wohlfahrt J, Jensen PK, Melbye M. 2009. Recurrence of congenital heart defects in families. Circulation 120: 295-301.

Pabst S, Wollnik B, Rohmann E, Hintz Y, Glanzer K, Vetter H, Nickenig G, Grohe C. 2008. A novel stop mutation truncating critical regions of the cardiac transcription factor NKX2-5 in a large family with autosomal-dominant inherited congenital heart disease. Clin Res Cardiol 97: 39-42.

Pashmforoush M, Lu JT, Chen H, Amand TS, Kondo R, Pradervand S, Evans SM, Clark B, Feramisco JR, Giles W, Ho SY, Benson DW, Silberbach M, Shou W, Chien KR. 2004. Nkx2-5 pathways and congenital heart disease; loss of ventricular myocyte lineage specification leads to progressive cardiomyopathy and complete heart block. Cell 117: 373386.

Perez-Duran P, de Yebenes VG, Ramiro AR. 2007. Oncogenic events triggered by AID, the adverse effect of antibody diversification. Carcinogenesis 28: 2427-2433. 
Perera F, Hemminki K, Jedrychowski W, Whyatt R, Campbell U, Hsu Y, Santella R, Albertini R, O'Neill JP. 2002. In utero DNA damage from environmental pollution is associated with somatic gene mutation in newborns. Cancer Epidemiol Biomarkers Prev 11: $1134-1137$.

Posch MG, Perrot A, Schmitt K, Mittelhaus S, Esenwein EM, Stiller B, Geier C, Dietz R, Gessner R, Ozcelik C, Berger F. 2008. Mutations in GATA4, NKX2.5, CRELD1, and BMP4 are infrequently found in patients with congenital cardiac septal defects. Am J Med Genet A 146: 251-253.

Prall OW, Menon MK, Solloway MJ, Watanabe Y, Zaffran S, Bajolle F, Biben C, McBride JJ, Robertson BR, Chaulet H, Stennard FA, Wise N, Schaft D, Wolstein O, Furtado MB, Shiratori H, Chien KR, Hamada H, Black BL, Saga Y, Robertson EJ, Buckingham ME, Harvey RP. 2007. An Nkx2-5/Bmp2/Smad1 negative feedback loop controls heart progenitor specification and proliferation. Cell 128: 947-959.

Rajagopal SK, Ma Q, Obler D, Shen J, Manichaikul A, Tomita-Mitchell A, Boardman K, Briggs C, Garg V, Srivastava D, Goldmuntz E, Broman KW, Woodrow BD, Smoot LB, Pu WT. 2007. Spectrum of heart disease associated with murine and human GATA4 mutation. J Mol Cell Cardiol 43:677-685.

Rauch R, Hofbeck M, Zweier C, Koch A, Zink S, Hoyer J, Kaulitz R, Singer H, Rauch A. 2010. Comprehensive genotype-phenotype analysis in 230 patients with tetralogy of Fallot. J Med Genet 47:321-331

Reamon-Buettner SM, Borlak J. 2004. Somatic NKX2-5 mutations as a novel mechanism of disease in complex congenital heart disease. J Med Genet 41: 684-690.

Reamon-Buettner SM, Hecker H, Spanel-Borowski K, Craatz S, Kuenzel E, Borlak J. 2004. Novel NKX2-5 mutations in diseased heart tissues of patients with cardiac malformations. Am J Pathol 164: 2117-2125. 
Reamon-Buettner SM, Ciribilli Y, Inga A, Borlak J. 2008. A loss-of-function mutation in the binding domain of HAND1 predicts hypoplasia of the human hearts. Hum Mol Genet 17: 1397-1405.

Reamon-Buettner SM, Ciribilli Y, Traverso I, Kuhls B, Inga A, Borlak J. 2009. A functional genetic study identifies HAND1 mutations in septation defects of the human heart. Hum Mol Genet 18: 3567-3578.

Roessler E, Ouspenskaia MV, Karkera JD, Velez JI, Kantipong A, Lacbawan F, Bowers P, Belmont JW, Towbin JA, Goldmuntz E, Feldman B, Muenke M. 2008. Reduced NODAL signaling strength via mutation of several pathway members including FOXH1 is linked to human heart defects and holoprosencephaly. Am J Hum Genet 83: 18-29.

Rifai L, Maazouzi W, Sefiani A. 2006. Novel point mutation in the NKX2-5 gene in a Moroccan family with atrioventricular conduction disturbance and an atrial septal defect in the oval fossa. Cardiol Young 17: 107-109.

Rochais F, Mesbah K, Kelly RG. 2009. Signaling pathways controlling second heart field development. Circ Res 104: 933-942.

Sarkozy A, Conti E, Neri C, D'Agostino R, Digilio MC, Esposito G, Toscano A, Marino B, Pizzuti A, Dallapiccola B. 2005. Spectrum of atrial septal defects associated with mutations of NKX2.5 and GATA4 transcription factors. J Med Genet 42: e16.

Sauna ZE, Kimchi-Sarfaty C, Ambudkar SV, Gottesman MM. 2007. Silent polymorphisms speak: how they affect pharmacogenomics and the treatment of cancer. Cancer Res 67: 9609-9612.

Saxena A, Tabin CJ. 2010. miRNA-processing enzyme Dicer is necessary for cardiac outflow tract alignment and chamber septation. Proc Natl Acad Sci U S A 107:87-91.

Schott JJ, Benson DW, Basson CT, Pease W, Silberbach GM, Moak JP, Maron BJ, Seidman CE, Seidman JG. 1998. Congenital heart disease caused by mutations in the transcription factor NKX2-5. Science 281: 108-111. 
Stankunas K, Hang CT, Tsun ZY, Chen H, Lee NV, Wu JI, Shang C, Bayle JH, Shou W, Iruela-Arispe ML, Chang CP. 2008a. Endocardial Brg1 represses ADAMTS1 to maintain the microenvironment for myocardial morphogenesis. Dev Cell 14: 298-311.

Stankunas K, Shang C, Twu KY, Kao SC, Jenkins NA, Copeland NG, Sanyal M, Selleri L, Cleary ML, Chang CP. 2008b. Pbx/Meis deficiencies demonstrate multigenetic origins of congenital heart disease. Circ Res 103: 702-709.

Takeda M, Briggs LE, Wakimoto H, Marks MH, Warren SA, Lu JT, Weinberg EO, Robertson KD, Chien KR, Kasahara H. 2009. Slow progressive conduction and contraction defects in loss of Nkx2-5 mice after cardiomyocyte terminal differentiation. Lab Invest 89: 983-993.

Targoff KL, Schell T, Yelon D. 2008. Nkx genes regulate heart tube extension and exert differential effects on ventricular and atrial cell number. Dev Biol 322: 314-321.

Teng G, Papavasiliou FN. 2007. Immunoglobulin somatic hypermutation. Annu Rev Genet 41: $107-120$.

Tsoutsman T, Bagnall RD, Semsarian C. 2008a. Impact of multiple gene mutations in determining the severity of cardiomyopathy and heart failure. Clin Exp Pharmacol Physiol 35: $1349-1357$.

Tsoutsman T, Kelly M, Ng DC, Tan JE, Tu E, Lam L, Bogoyevitch MA, Seidman CE, Seidman JG, Semsarian C. 2008b. Severe heart failure and early mortality in a doublemutation mouse model of familial hypertrophic cardiomyopathy. Circulation 117: 18201831.

Vincentz JW, Barnes RM, Firulli BA, Conway SJ, Firulli AB. 2008. Cooperative interaction of Nkx2.5 and Mef2c transcription factors during heart development. Dev Dyn 237: 38093819.

Wagner M, Siddiqui MA. 2007a. Signal transduction in early heart development (I): cardiogenic induction and heart tube formation. Exp Biol Med (Maywood ) 232: 852-865. 
Wagner M, Siddiqui MA. 2007b. Signal transduction in early heart development (II): ventricular chamber specification, trabeculation, and heart valve formation. Exp Biol Med 232: 866-880.

Wang Z, Zhai W, Richardson JA, Olson EN, Meneses JJ, Firpo MT, Kang C, Skarnes WC, Tjian R. 2004. Polybromo protein BAF180 functions in mammalian cardiac chamber maturation. Genes Dev 18: 3106-3116.

Watanabe Y, Benson DW, Yano S, Akagi T, Yoshino M, Murray JC. 2002. Two novel frameshift mutations in NKX2.5 result in novel features including visceral inversus and sinus venosus type ASD. J Med Genet 39: 807-811.

Weismann CG, Gelb BD. 2007. The genetics of congenital heart disease: a review of recent developments. Curr Opin Cardiol 22: 200-206.

Winston JB, Erlich JM, Green CA, Aluko A, Kaiser KA, Takematsu M, Barlow RS, Sureka AO, LaPage MJ, Janss LL, Jay PY. 2010. Heterogeneity of genetic modifiers ensures normal cardiac development. Circulation 121: 1313-1321.

Zhang W, Li X, Shen A, Jiao W, Guan X, Li Z. 2009a. Screening NXK2.5 mutation in a sample of 230 Han Chinese children with congenital heart diseases. Genet Test Mol Biomarkers 13: 159-162.

Zhang WM, Li XF, Ma ZY, Zhang J, Zhou SH, Li T, Shi L, Li ZZ. 2009b. GATA4 and NKX2.5 gene analysis in Chinese Uygur patients with congenital heart disease. Chin Med J (Engl) 122: 416-419.

Zhou B, von Gise A, Ma Q, Rivera-Feliciano J, Pu WT. 2008. Nkx2-5- and Is11-expressing cardiac progenitors contribute to proepicardium. Biochem Biophys Res Commun 375: 450453.

Zhu W, Shiojima I, Hiroi Y, Zou Y, Akazawa H, Mizukami M, Toko H, Yazaki Y, Nagai R, Komuro I. 2000. Functional analyses of three Csx/ $\mathrm{Nkx}-2.5$ mutations that cause human congenital heart disease. J Biol Chem 275: 35291-35296. 


\section{Legend to Figures}

Figure 1. Summary of germline $N K X 2-5$ mutations in $\mathrm{CHD}$, detection frequency in sporadic or familial cases, and associated cardiac malformations.

Figure 2. Facts about germline $N K X 2-5$ mutations.

Figure 3. Predictions of the effect of NKX2-5 mutations on the secondary structure of the protein. NKX2-5 interacts with DNA through a helix-turn-helix DNA-binding motif of three alpha helices within the homeodomain (HD). The amino acids in the alpha helices are underlined and those affected by $N K X 2-5$ mutations are indicated by asterisks. Some $N K X 2-5$ mutations can lead to breakage of the structure (arrows), and thus a truncated protein. For predictions, amino acids in the Swiss Model for NKX2-5 (P52952) (http://swissmodel.expasy.org) were mutated using tools contained in Swiss-PdbViewer (http://spdbv.vital-it.ch/), and the resulting structure viewed through Protein Explorer (http://proteinexplorer.org).

Figure 4. NKX2-5 mutations affect conserved regions of the homeodomain. Protein modelling and identification of conserved regions were undertaken using Consurf (http://consurf.tau.ac.il/) and Chimera (http://www.cgl.ucsf.edu/chimera/). 
Table 1. Functional Consequences of Identified NKX2-5 Mutations in CHD: Functional Assays or Bioinformatic Analysis

\begin{tabular}{|c|c|}
\hline Functional Consequence & Mutations*** \\
\hline 5 truncated protein before $\mathrm{HD}$ & $\begin{array}{l}\text { c.215_221del AGCTGGG, p.E72fs } \\
\text { c.223_224delCG, p.P77fs } \\
\text { c.262delG, p.A88fs } \\
\text { c.312delG, p.D105fs } \\
\text { c.325G>T, p.E109X }\end{array}$ \\
\hline 6 truncated protein within HD & $\begin{array}{l}\text { c. } 445 \mathrm{C}>\mathrm{T}, \mathrm{p} . \mathrm{Q} 149 \mathrm{X} \\
\text { c. } 498 \_499 \text { insC, p.E167fs } \\
\text { c. } 508 \mathrm{C}>\mathrm{T}, \mathrm{p} . \mathrm{Q} 170 \mathrm{X} \\
\text { c.533C }>\mathrm{T} \text {, p.T178M } \\
\text { c.561G }>\mathrm{C}, \text { p.Q187H } \\
\text { c.564C }>\text { A, p.N188K }\end{array}$ \\
\hline 2 truncated protein after HD & $\begin{array}{l}\text { c. } 592 \mathrm{C}>\mathrm{T}, \mathrm{p} . \mathrm{Q} 198 \mathrm{X} \\
\text { c. } 605 \_606 \mathrm{delTG}, \mathrm{p} . \mathrm{L} 202 \mathrm{fs}\end{array}$ \\
\hline 4 truncated protein after NK2-SD & $\begin{array}{l}\text { c.701_702insTCCCT, p.A235fs } \\
\text { c.768T>A, p.Y256X } \\
\text { c.777C }>\text { A, p.Y259X } \\
\text { c.792C }>\text { A, p.C264X }\end{array}$ \\
\hline $\begin{array}{l}16 \text { defective in functional assays* } \\
\text { (DNA binding/transactivation } \\
\text { activity/protein-protein interaction/ } \\
\text { nuclear localization) }\end{array}$ & 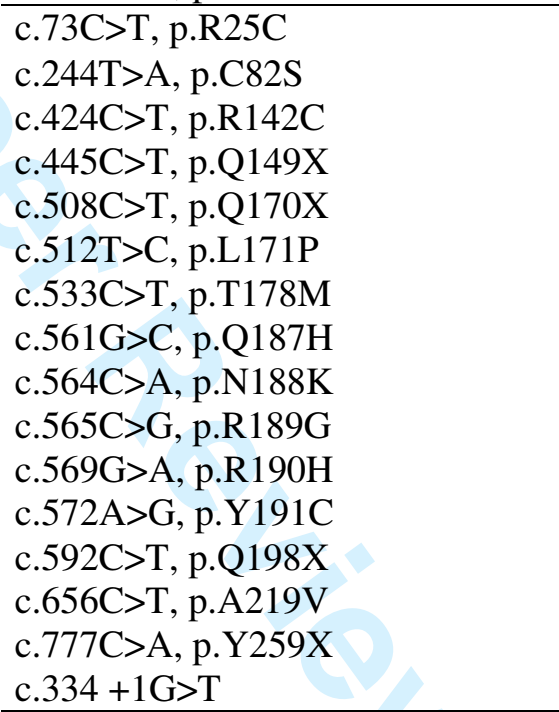 \\
\hline 8 predicted to be damaging** & $\begin{array}{l}\text { c. } 44 \mathrm{~A}>\mathrm{T}, \mathrm{p} . \mathrm{K} 15 \mathrm{I} \\
\text { c.61G }>\text { C, p.E21Q } \\
\text { c. } 65 \mathrm{~A}>\mathrm{C}, \mathrm{p} . \mathrm{Q} 22 \mathrm{P} \\
\text { c.65A }>\text { G, p.Q22R } \\
\text { c.479A }>\text { C, p.Q160P } \\
\text { c.554G }>\text { T, p.W185L } \\
\text { c.823C }>\text { A, p.P275T } \\
\text { c. } 967 \mathrm{G}>\text { A, p.A323T }\end{array}$ \\
\hline 4 predicted to be tolerated ${ }^{* *}$ & $\begin{array}{l}\text { c. } 124 \mathrm{G}>\mathrm{C}, \text { p.A42P } \\
\text { c. } 188 \mathrm{C}>\mathrm{T}, \text { p.A63V } \\
\text { c.380C }>\text { A, p.A127E } \\
\text { c. } 839 \mathrm{C}>\mathrm{T}, \text { p.P280L }\end{array}$ \\
\hline
\end{tabular}

\footnotetext{
* For the functional studies, see (Kasahara et al., 2000;Kasahara and Benson, 2004;Zhu et al., 2000;Monzen et al., 2002; Inga et al., 2005; Esposito et al., 2009).

** predicted by PolyPhen (http://genetics.bwh.harvard.edu/pph/); SIFT (http://sift.jcvi.org/)

$* * *$ Nucleotide numbering reflects cDNA numbering with +1 corresponding to the A of the ATG translation initiation codon in the reference sequence NM_0004387.3, according to journal guidelines

(www.hgvs.org/mutnomen). The initiation codon is codon 1.
} 
Table 2. Detection Frequency of NKX2-5 Germline Mutations in Congenital Heart Disease

\begin{tabular}{cccll}
\hline $\begin{array}{c}\text { Mutation- } \\
\text { Positive } \\
\text { Patients }\end{array}$ & $\begin{array}{c}\text { Patients } \\
\text { Analyzed }\end{array}$ & $\begin{array}{c}\text { Frequency } \\
(\boldsymbol{\%})\end{array}$ & \multicolumn{1}{c}{ Study } & \multicolumn{1}{c}{$\begin{array}{c}\text { Country } \\
\text { Study/Patients }\end{array}$} \\
\hline 1 & 109 & 0.9 & (Ikeda et al., 2002) & Japan \\
18 & 608 & 3.0 & (McElhinney et al., 2003) & USA \\
2 & 146 & 1.4 & (Elliott et al., 2003) & Australia, USA \\
0 & 227 & 0 & (Hobbs et al., 2005) & USA \\
3 & 16 & 18.8 & (Hirayama-Yamada et al., 2005) & Japan \\
0 & 205 & 0 & (Posch et al., 2008) & Germany \\
1 & 72 & 1.4 & (Akcaboy et al., 2008) & Turkey \\
2 & 159 & 1.3 & (Gioli-Pereira et al., 2010) & Brazil \\
0 & 230 & 0 & (Zhang et al., 2009a) & China \\
0 & 62 & 0 & (Zhang et al., 2009b) & China \\
6 & 125 & 4.8 & (Esposito et al., 2009) & Italy \\
0 & 104 & 0 & (Hamanoue et al., 2009) & Indonesia \\
\hline 33 & 2063 & 2.0 & Total & \\
\hline
\end{tabular}



and associated cardiac malformations. $215 \times 189 \mathrm{~mm}$ (300 x 300 DPI)

Malformations

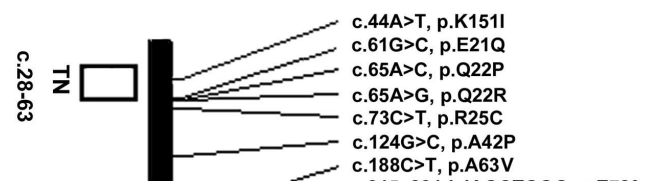

作

c. 223 224delCG, p.77fs

c.262delG, p.A88fs

c.312delG, p.D105fs

c.325G >T, p.E109X

c.424C $>T, p . R 142 C$

c.445C>T, p.Q149X

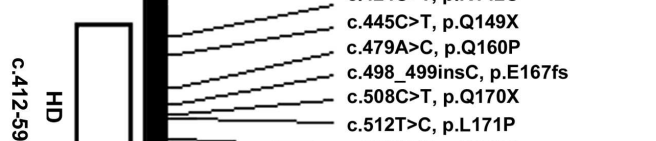

Mutation + CHD $\overline{\text { AV block ASD II TOF VSD Others }}$

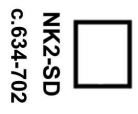

, p.L171P

c.533C $>T$, p.T178M

c.554G $>\mathrm{T}$, p.W185L

c.561G>C, p.Q187H

$c .565 C>G, p . R 189 G$

c. $568 \mathrm{C}>\mathrm{T}, \mathrm{p} . \mathrm{R} 190 \mathrm{C}$

c.572A>G, p.Y191C

c.592C $>T$, p.Q198X

c.605_606delTG, p.L202fs

c. $646 \mathrm{C}>\mathrm{T}, \mathrm{p} . \mathrm{R} 216 \mathrm{C}$

c.656C $>\mathrm{T}, \mathrm{p} . \mathrm{A} 219 \mathrm{~V}$

c.701 702ins TCCCT, p.A235fs

c.768T >A, p.Y256X

c.777C $>A$, p.Y259X

c.792C $>A$, p.C264X

c. $823 \mathrm{C}>\mathrm{A}, \mathrm{p} . \mathrm{P} 275 \mathrm{~T}$

c.839C>T, p.P280L

c.871_873delAAC, $p$,
$c .967 \mathrm{G}>\mathrm{A}, \mathrm{p} . \mathrm{A323T}$

Summary of germline NKX2-5 mutations in CHD, detection frequency in sporadic or familial cases,

John Wiley \& Sons, Inc. 
Facts about germline NKX2-5 mutations. $227 \times 188 \mathrm{~mm}(300 \times 300 \mathrm{DPI})$ 
324 aa
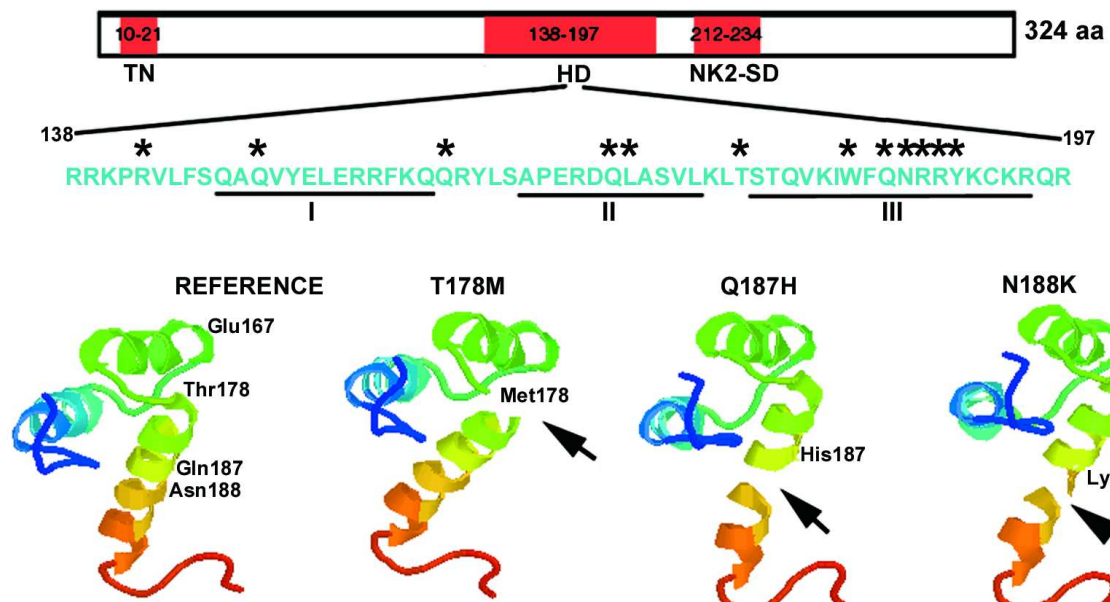

N188K
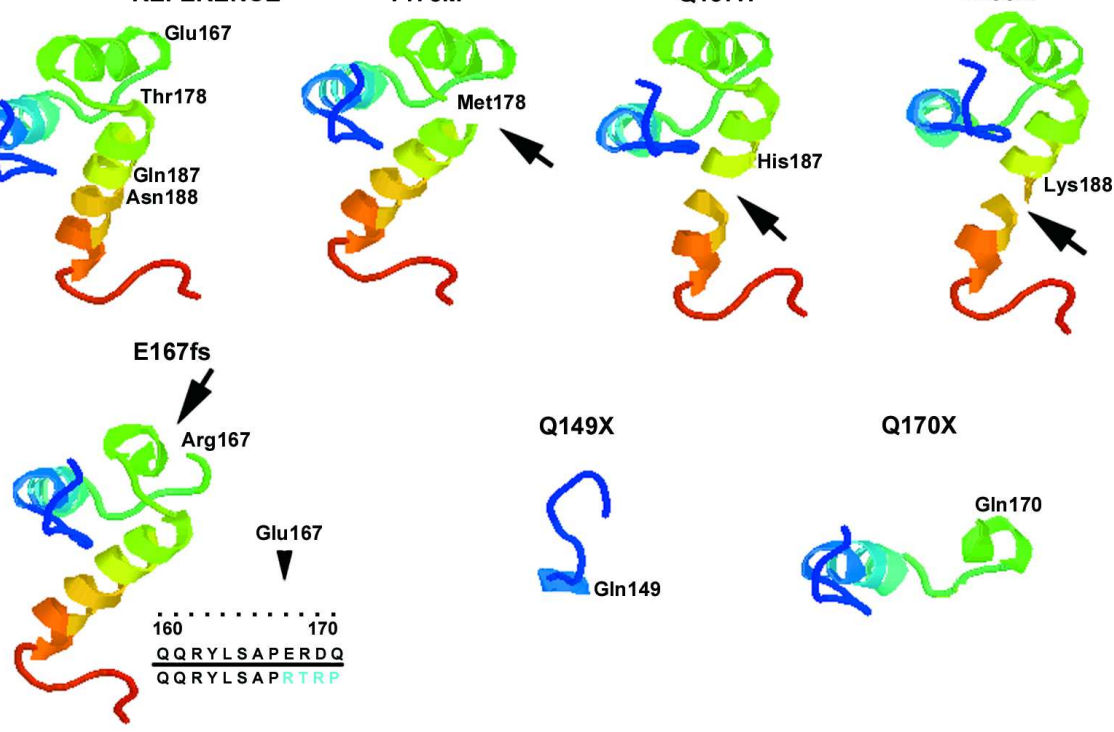

Q149X

Q170X
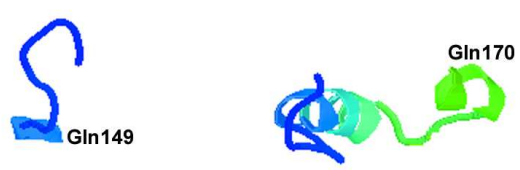

Predictions of the effect of NKX2-5 mutations on the secondary structure of the protein. NKX2-5 interacts with DNA through a helix-turn-helix DNA-binding motif of three alpha helices within the homeodomain (HD). The amino acids in the alpha helices are underlined and those affected by NKX2-5 mutations are indicated by asterisks. Some NKX2-5 mutations can lead to breakage of the structure (arrows), and thus a truncated protein. For predictions, amino acids in the Swiss Model for NKX2-5 (P52952) (http://swissmodel.expasy.org) were mutated using tools contained in SwissPdbViewer (http://spdbv.vital-it.ch/), and the resulting structure viewed through Protein Explorer (http://proteinexplorer.org). $227 \times 188 \mathrm{~mm}(200 \times 200 \mathrm{DPI})$ 
324 aa
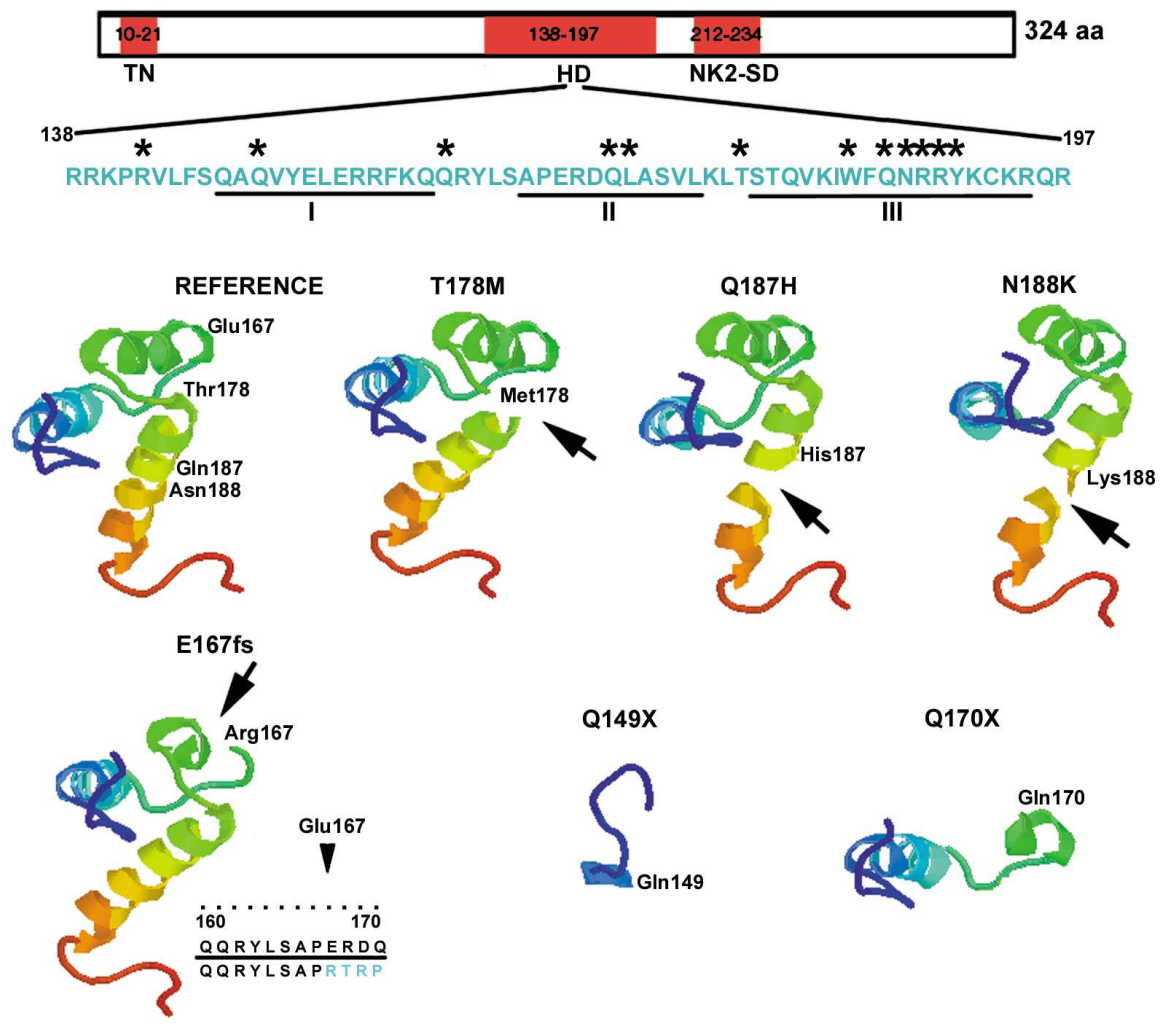

Q149X

Q170X

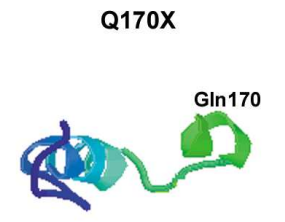

Predictions of the effect of NKX2-5 mutations on the secondary structure of the protein. NKX2-5 interacts with DNA through a helix-turn-helix DNA-binding motif of three alpha helices within the homeodomain (HD). The amino acids in the alpha helices are underlined and those affected by NKX2-5 mutations are indicated by asterisks. Some NKX2-5 mutations can lead to breakage of the structure (arrows), and thus a truncated protein. For predictions, amino acids in the Swiss Model for NKX2-5 (P52952) (http://swissmodel.expasy.org) were mutated using tools contained in SwissPdbViewer (http://spdbv.vital-it.ch/), and the resulting structure viewed through Protein Explorer (http://proteinexplorer.org). $227 \times 188 \mathrm{~mm}(200 \times 200 \mathrm{DPI})$ 
NKX2-5 mutations affect conserved regions of the homeodomain. Protein modelling and identification of conserved regions were undertaken using Consurf (http://consurf.tau.ac.il/) and Chimera (http://www.cgl.ucsf.edu/chimera/). $187 \times 155 \mathrm{~mm}(300 \times 300$ DPI $)$ 
NKX2-5 mutations affect conserved regions of the homeodomain. Protein modelling and identification of conserved regions were undertaken using Consurf (http://consurf.tau.ac.il/) and Chimera (http://www.cgl.ucsf.edu/chimera/). $187 \times 155 \mathrm{~mm}(300 \times 300 \mathrm{DPI})$ 
Supp. Figure S1. Geographical distribution of germline NKX2-5 mutations in CHD along the coding sequence of the gene.

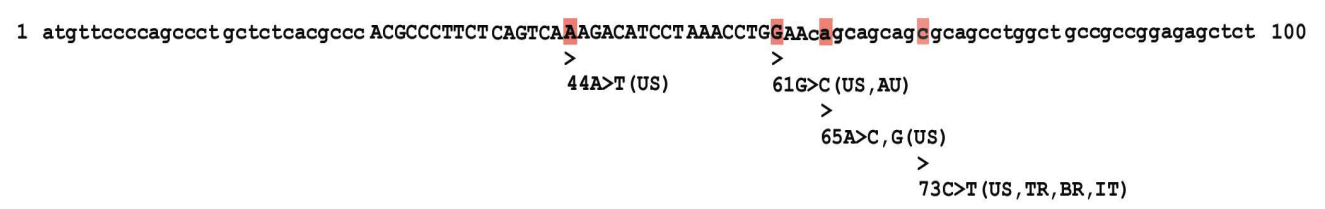

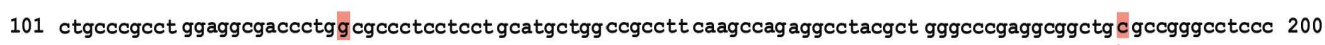
$124 \mathrm{G}>\mathrm{C}(\mathrm{BR})$ $188 \mathrm{C}>\mathrm{T}$ (US)

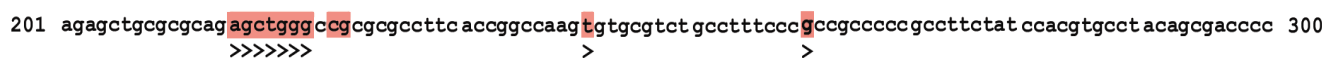
$244 \mathrm{~T}>\mathrm{A}(\mathrm{IT}) \quad 262 \mathrm{del}(\mathrm{JP})$ 223_224del (JP)

301 gacccagccaa ggaccctagagccgaaaagaaa gagctgtgcgcg ctgcagaaggcggt ggagctg gagaagacagagg cggacaacgcggagcggcccc 400 $>$ $380 \mathrm{C}>\mathrm{A}$ (US) 325G>T (DE)

401 gggegegacgg CGGAGGAAGCCG CGCGTGCTCTICT CGCAGGCG CAGGTCTAT GAGCTGGAGC GGCGCTTCAAGCAGCÄGCGGTACCT GTCGGCCCCCA 500 $>$ $\begin{array}{llll}>424 \mathrm{C}>\mathrm{T}(\mathrm{BE}) & > & > & > \\ 445 \mathrm{C}>\mathrm{T}(\mathrm{US}, \mathrm{NO}) & 479 \mathrm{~A}>\mathrm{C}(\mathrm{MA}) & 498^{\wedge} 499 \mathrm{insC}(\mathrm{IT})\end{array}$

501 ACGCGACCAGCTGGCCAGCGTGCT GAAACTCACGTCCACGCA GTCAAGATCT GGTTCCAGAACG GGCGCTÄAAAGT GCAAGCGGCAGCGGCaggaccag 600 $\begin{array}{llclc}> & > & > & > \\ 508 \mathrm{C}>\mathrm{T} \text { (US) } & 533 \mathrm{C}>\mathrm{T}(\mathrm{US}, \mathrm{JP}, \mathrm{AU}) & 554 \mathrm{G}>\mathrm{T}(\mathrm{IT}) & 568 \mathrm{C}>\mathrm{T} \text { (JP) } & 592 \mathrm{C}>\mathrm{T} \text { (US }, \mathrm{JP})\end{array}$ $512 \mathrm{~T}>\mathrm{C}$ (US) 561G>C (BE) $>$ $564 \mathrm{C}>\mathrm{A}$ (US) $565 \mathrm{C}>\mathrm{G}$ (US) 569G>A (US) $572 A>G$ (US)

601 actc tg gagctggt ggggct geccce gccgccgCCGCCGCCTGCC CGCAGGATCGCGGTGCCA GTGCT GGTGCGCGAT GGCAAGCC ATGCCT AGGGGACT 700 $605 \_606 \mathrm{del}$ (IT) $646 \mathrm{C}>\mathrm{T}$ (US) 656C>T (US)

701 CGgcgccctacgcgectgcct acggcgtgggect caatccet acggttat aacgcct accccgcctatccgggttacggcggcgcggcetgcagccetgg 800 $\begin{array}{lll}> & > & > \\ 701^{\wedge} 702 \text { insTCCCT (US) } & 768 \mathrm{~T}>\mathrm{A}(\mathrm{BE}) & 792 \mathrm{C}>\mathrm{A}(\mathrm{JP})\end{array}$ $\begin{aligned}> & \\ 777 \mathrm{C}>\mathrm{A}(\mathrm{US}) & \end{aligned}$

801 ctacagctgcactg cegcttacccegecgggecttccecagcgcagccggecact gecgccgccaacaacaacttcgt gaacttcggcgt cggggacttg 900 $\begin{array}{lll}> & > & \gg> \\ 823 \mathrm{C}>\mathrm{A}(\mathrm{US}) & 839 \mathrm{C}>\mathrm{T} \text { (IT) } & 871 \_873 \mathrm{del} \text { (US) }\end{array}$

901 aatgcggttca gagccce gggattccgcaga gcaactcgggagtgtccacgctgcatggtatccgagcctggtag 975 967G>A (US) 
Supp. Table S1. Studies on NKX2-5 Mutations Associated with Congenital Heart Disease (CHD)

\begin{tabular}{|c|c|c|c|}
\hline \multirow[t]{2}{*}{ Ref. No. } & \multirow[t]{2}{*}{ Authors/Year } & \multicolumn{2}{|c|}{ NKX2-5 Germline Mutation } \\
\hline & & present & absent \\
\hline 1 & Schott et al., 1998 & $\mathrm{X}$ & \\
\hline 2 & Benson et al., 1999 & $\mathrm{x}$ & \\
\hline 3 & Hosoda et al., 1999 & $\mathrm{x}$ & \\
\hline 4 & Goldmuntz et al., 2001 & $\mathrm{x}$ & \\
\hline 5 & Watanabe et al., 2002 & $\mathrm{x}$ & \\
\hline 6 & Ikeda et al., 2002 & $\mathrm{x}$ & \\
\hline 7 & Gutierrez-Roelens et al., 2002 & $\mathrm{x}$ & \\
\hline 8 & McElhinney et al., 2003 & $\mathrm{x}$ & \\
\hline 9 & Elliott et al., 2003 & $\mathrm{x}$ & \\
\hline 10 & Kasahara and Benson, 2004 & $\mathrm{x}$ & \\
\hline 11 & Sarkozy et al., 2005 & $\mathrm{x}$ & \\
\hline 12 & Hobbs et al., 2005 & & $\mathrm{x}$ \\
\hline 13 & Hirayama-Yamada et al., 2005 & $\mathrm{x}$ & \\
\hline 14 & Gutierrez-Roelens et al., 2006 & $\mathrm{x}$ & \\
\hline 15 & Rifai et al., 2006 & $\mathrm{x}$ & \\
\hline 16 & Konig et al., 2006 & $\mathrm{x}$ & \\
\hline 17 & Majumdar et al., 2006 & & $\mathrm{x}$ \\
\hline 18 & Pabst et al., 2008 & $\mathrm{x}$ & \\
\hline 19 & Akcaboy et al., 2008 & $\mathrm{x}$ & \\
\hline 20 & Posch et al., 2008 & & $\mathrm{x}$ \\
\hline 21 & Khetyar et al., 2008 & & $\mathrm{x}$ \\
\hline 22 & Bjornstad and Leren, 2009 & $\mathrm{x}$ & \\
\hline 23 & Esposito et al., 2009 & $\mathrm{x}$ & \\
\hline 24 & Draus, Jr. et al., 2009 & $\mathrm{x}$ & \\
\hline 25 & Hamanoue et al., 2009 & & $\mathrm{x}$ \\
\hline 26 & Zhang et al., 2009a & & $\mathrm{x}$ \\
\hline 27 & Zhang et al., 2009b & & $\mathrm{x}$ \\
\hline 28 & Gioli-Pereira et al., 2010 & $\mathrm{x}$ & \\
\hline
\end{tabular}


Supp. Table S2. Summary of Published Germline NKX2-5 Mutations in Patients with Congenital Heart Defects

\begin{tabular}{|c|c|c|c|c|c|c|c|c|}
\hline No. & Mutation & $\begin{array}{l}\text { Amino acid } \\
\text { change }\end{array}$ & $\begin{array}{l}\text { Gene } \\
\text { region }\end{array}$ & $\begin{array}{l}\text { Phenotypes of } \\
\text { mutation- } \\
\text { positive patients }\end{array}$ & $\begin{array}{l}\text { Occurrence } \\
\text { of CHD }\end{array}$ & $\begin{array}{l}\text { No. of mutation-positive } \\
\text { CHD patients }\end{array}$ & Authors & $\begin{array}{l}\text { Country } \\
\text { where study } \\
\text { conducted }\end{array}$ \\
\hline 1 & c. $44 \mathrm{~A}>\mathrm{T}$ & p.K15I & $\begin{array}{l}\mathrm{TN} \\
\text { domain }\end{array}$ & ASD II & sporadic & $\mathrm{n}=1$ & $\begin{array}{l}\text { McElhinney et } \\
\text { al., 2003) }\end{array}$ & USA \\
\hline 2. & c. $61 \mathrm{G}>\mathrm{C}$ & p.E21Q & $\begin{array}{l}\mathrm{TN} \\
\text { domain }\end{array}$ & TOF & sporadic & $\begin{array}{l}\mathrm{n}=1 \\
(2 \text { unaffected family } \\
\text { members positive) }\end{array}$ & $\begin{array}{l}\text { (Goldmuntz et } \\
\text { al., 2001) } \\
\text { (McElhinney et } \\
\text { al., 2003) }\end{array}$ & USA \\
\hline & c. $61 \mathrm{G}>\mathrm{C}$ & & & ASD II & familial & $\begin{array}{l}\mathrm{n}=1 \\
(2 \text { affected family } \\
\text { members negative) }\end{array}$ & $\begin{array}{l}\text { (Elliott et al., } \\
\text { 2003) }\end{array}$ & Australia \\
\hline 3. & c. $65 \mathrm{~A}>\mathrm{C}$ & p.Q22P & $\begin{array}{l}5 \text { ' coding } \\
\text { region }\end{array}$ & TOF & sporadic & $\mathrm{n}=1$ & $\begin{array}{l}\text { (McElhinney et } \\
\text { al., 2003) }\end{array}$ & USA \\
\hline 4. & c. $65 \mathrm{~A}>\mathrm{G}$ & p.Q22R & $\begin{array}{l}5^{\prime} \text { coding } \\
\text { region }\end{array}$ & ASD II & sporadic (?) & $\mathrm{n}=1$ & $\begin{array}{l}\text { (Draus, Jr. et } \\
\text { al., 2009) }\end{array}$ & USA \\
\hline 5. & c. $73 \mathrm{C}>\mathrm{T}$ & p.R25C & $\begin{array}{l}5^{\prime} \text { coding } \\
\text { region }\end{array}$ & $\begin{array}{l}\text { TOF, } \\
\text { VSD } \\
\text { conoventricular }\end{array}$ & sporadic & $\begin{array}{l}\mathrm{n}=1 \\
\text { (unaffected mother and } 2 \\
\text { brothers negative) }\end{array}$ & $\begin{array}{l}\text { (Benson et al., } \\
\text { 1999) }\end{array}$ & USA \\
\hline & c. $73 \mathrm{C}>\mathrm{T}$ & & & TOF & $\begin{array}{l}\text { sporadic/ } \\
\text { familial }\end{array}$ & $\begin{array}{l}\mathrm{n}=3 \\
\text { (also detected in an } \\
\text { affected father of a } \\
\text { positive patient, and in } 2 \\
\text { of } 43 \text { control) }\end{array}$ & $\begin{array}{l}\text { (Goldmuntz et } \\
\text { al., 2001) }\end{array}$ & USA \\
\hline & c. $73 \mathrm{C}>\mathrm{T}$ & & & $\begin{array}{l}\text { TOF, TA, } \\
\text { IAA,HLHS }\end{array}$ & $\begin{array}{l}\text { sporadic/ } \\
\text { familial }\end{array}$ & $\begin{array}{l}\mathrm{n}=7 \text { (includes } 4 \text { TOFs } \\
\text { Benson, Goldmuntz) } \\
4 \text { TOF (father of } 1 \text { TOF } \\
\text { had VSD and also } \\
\text { positive) } 1 \text { TA, } 1 \text { IAA and } \\
1 \text { HLHS }\end{array}$ & $\begin{array}{l}\text { (McElhinney et } \\
\text { al., 2003) }\end{array}$ & USA \\
\hline & c. $73 \mathrm{C}>\mathrm{T}$ & & & TOF & sporadic & $\begin{array}{l}\mathrm{n}=1 \\
\text { (also detected in the } \\
\text { unaffected father of }\end{array}$ & $\begin{array}{l}\text { (Akcaboy et } \\
\text { al., 2008) }\end{array}$ & Turkey \\
\hline
\end{tabular}


c. $73 \mathrm{C}>\mathrm{T}$

c. $73 \mathrm{C}>\mathrm{T}$

6. (c. $124 \mathrm{G}>\mathrm{C}) * *$

7. c. $188 \mathrm{C}>\mathrm{T}$

8. c.215_221del AGCTGGG

9. c.223 224delCG

10. c. $244 \mathrm{~T}>\mathrm{A}$

11. c.262delG

12. c.312delG

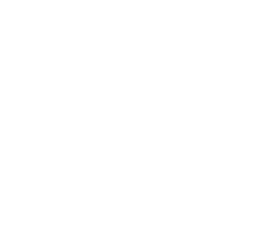

+PDA+right

sided-aortic arch

familial

accessory

atrioventricular

connection

Ebstein's

region anomaly

5 ' coding

L-TGA

region

5' coding

region

AV block, ASD familial

(3 sinus venosus

type)

sporadic,

familial

sporadic

sporadic

familial

(4 AV block + ASD; 1

$\mathrm{AF})$

$$
\begin{aligned}
& \text { p. R75fs } \\
& \text { (p.P77fs)** }
\end{aligned}
$$

5' coding

AV block,

ASD II

p.C82S

5 ' coding

region

p.A88fs

5' coding

region

accessory

atrioventricular

connection

AV block,

ASD II

p.K104fs

(p.D105fs)**

\section{5' coding} region $\mathrm{n}=1$

negative)

$\mathrm{n}=4$

(unaffected parents

positive)

(unaffected father

positive)

$\mathrm{n}=1$ cardiac malformation)

AV block, familial $\mathrm{n}=2$ patient, and 2 unrelated

ealthy contro

positive, sister with VSD

(Gioli-Pereira

Brazil

et al., 2010)

(Esposito et al., Italy 2009)

(Gioli-Pereira Brazil et al., 2010)

(McElhinney et USA al., 2003)

(Watanabe et Japan al., 2002)

(Watanabe et Japan al., 2002)

(Esposito et al., Italy 2009)

(HirayamaJapan (3 AV block +ASD II Yamada et al., 1 AV block without 2005)

(both AV block + ASD II)
(Konig et al., 2006) 


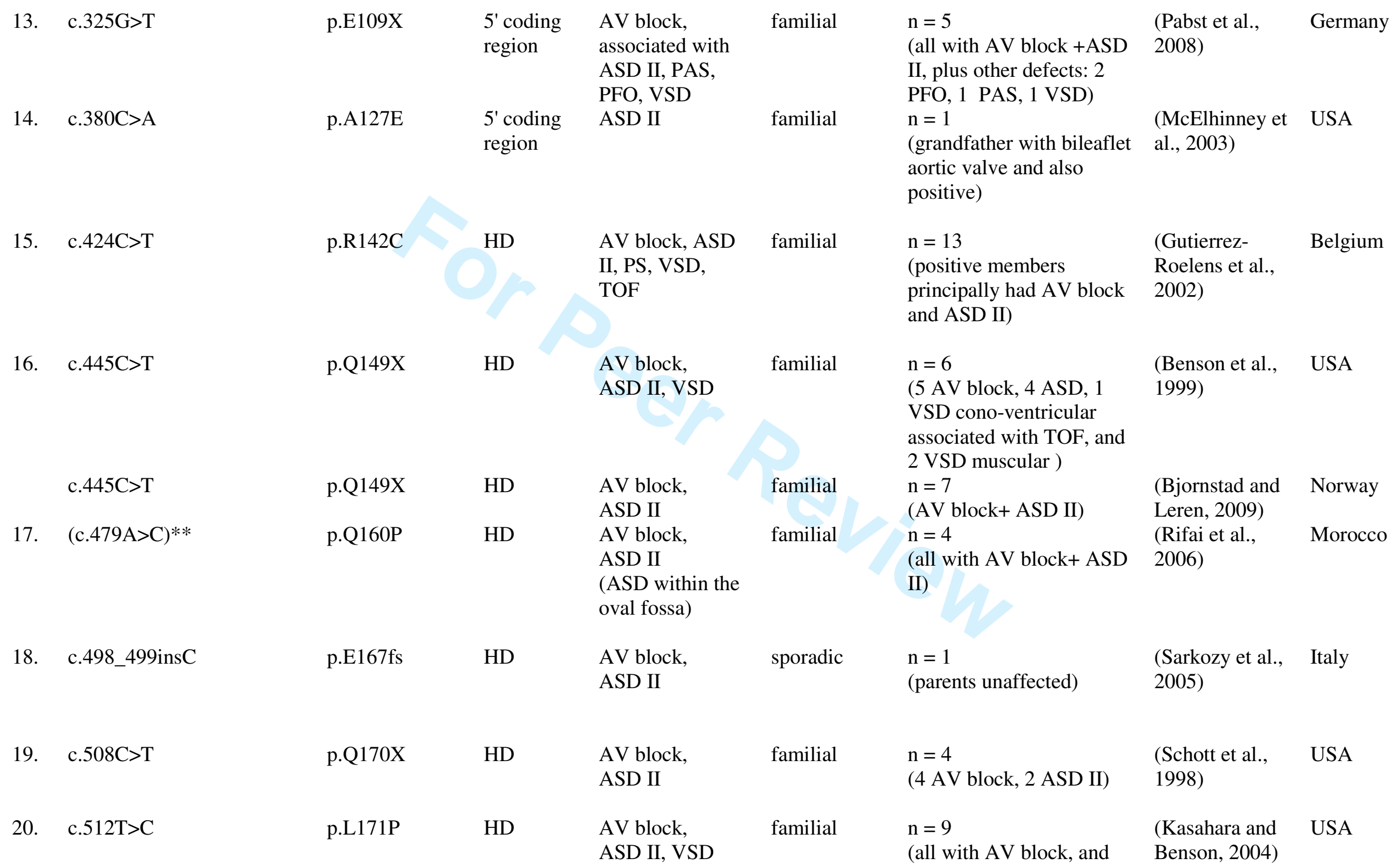


AV block, ASD II

c. $533 \mathrm{C}>\mathrm{T}$

AV block,

ASD II, atrial

fibrillation $(\mathrm{AF})$

c. $533 \mathrm{C}>\mathrm{T}$

ASD II,

HLHS

7 with ASD, 1 VSD)

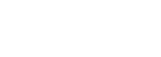

24. c. $564 \mathrm{C}>\mathrm{A}$

p.N188K

HD

AV block, ASD familial II, abnormal tricuspid valve, reduced $\mathrm{LV}$ function

25. c. $565 \mathrm{C}>\mathrm{G}$

p.R189G

HD $\mathrm{n}=5$ $\mathrm{n}=12$

11 ASD II)

$\mathrm{n}=2$

1 AV block+ASD II, 1 ASD II+AF)

$\mathrm{n}=3$

(1 phenotypically normal

family member also

positive; 1 ASD II

+ HLHS, 2 ASD II)

$\mathrm{n}=3$

(1 AV block +ASD II, 2

ASD II+ muscular VSD

(swiss-cheese VSD)

$\mathrm{n}=6$

( 2 positive members had

anomalous venous return)

1998)

(Hirayama-

Yamada et al.,

2005)

(Elliott et al., Australia

2003)

(Sarkozy et al., Italy

2005)

(Gutierrez-

Roelens et al.,

Belgium

USA

Japan 2002)
(Benson et al., USA

( 5 AV block, 5 ASD II, 3 1999)

abnormal TV, 1 reduced

LV function )

$\mathrm{n}=5$ (5 AV block ), 4

ASD, 1 abnormal TV, 3

(Benson et al.,

1999)

USA
II abnormal

tricuspid valve,

reduced LV

function 


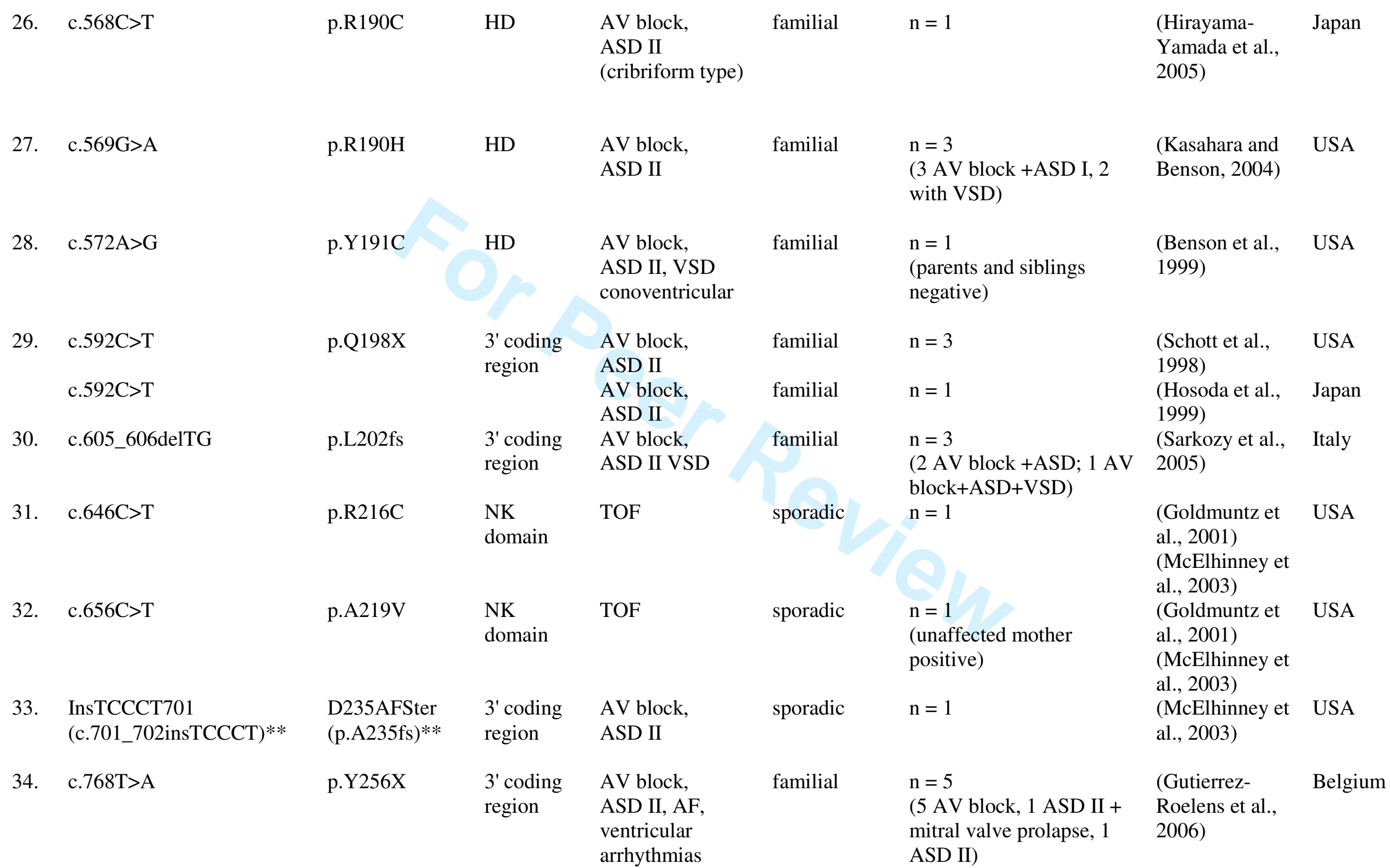




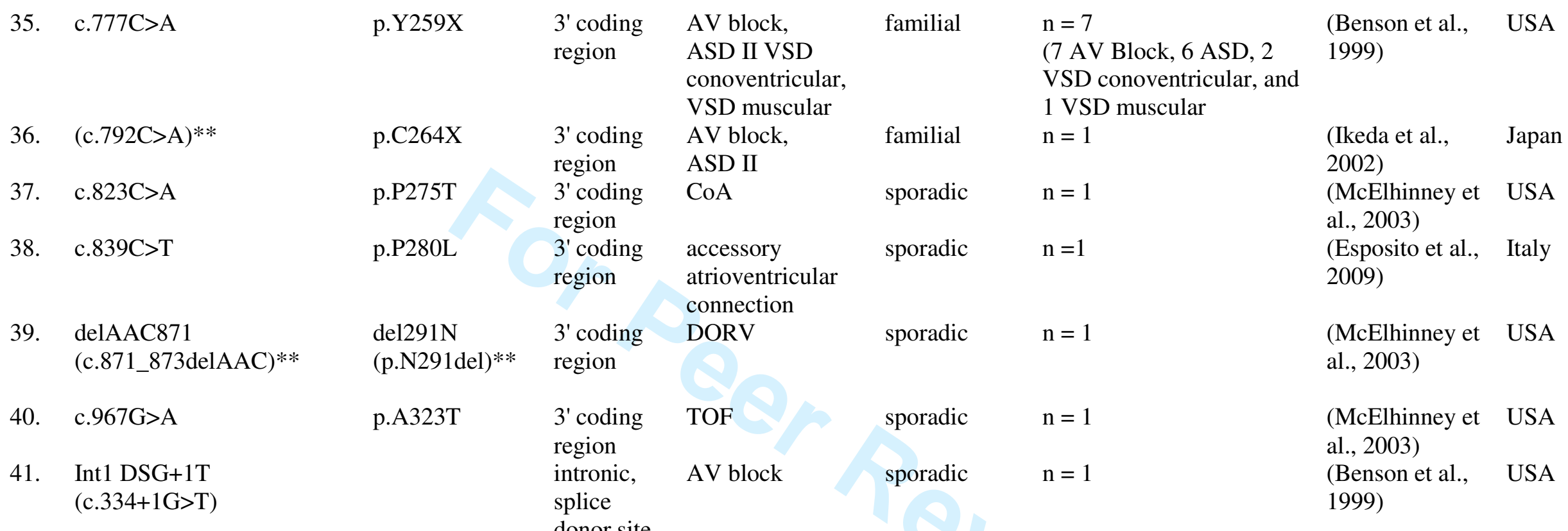

** supplied based on description in the paper or written in accordance with recommended mutation nomenclature. Nucleotide numbering reflects cDNA numbering with +1 corresponding to the A of the ATG translation initiation codon in the reference sequence NM_0004387.3, according to journal guidelines (www.hgvs.org/mutnomen). The initiation codon is codon 1.

Watanabe et al 2002: c.223_224delCG (p.P77fs because p.P77 is the first aa to be affected by the frameshift, p.A76 is silent change)

Koenig et al, 2006: c.312delG (p.D105fs because p.D105 is the first aa to be affected by the frameshift)

McElhinney et al, 2003: c.701_702insTCCCT (p.A235fs because p.S235 is the first aa to be affected by the frameshift, p.S234 is silent change)

Benson et al. 1999: Int1 DSG+1T (intron1, splice donor site (+1) G>T), c.334 +1G>T 
Supp. Table S3. Functional Significance of Published Germline NKX2-5 Mutations in Patients with Congenital Heart Disease

\begin{tabular}{|c|c|c|c|c|c|}
\hline No. & Mutation & Authors & Gene regon & $\begin{array}{l}\text { Function (as predicted by its location or bioinformatic analysis } \\
\text { and functional assays) }\end{array}$ & $\begin{array}{l}\text { Bioinformatic } \\
\text { methods/assays }\end{array}$ \\
\hline 1 & $\begin{array}{l}\text { c. } 44 \mathrm{~A}>\mathrm{T}, \\
\text { p.K15I }\end{array}$ & $\begin{array}{l}\text { (McElhinney et al., } \\
\text { 2003) }\end{array}$ & TN domain & damaging & SIFT/Polyphen \\
\hline 2. & $\begin{array}{l}\text { c. } 61 \mathrm{G}>\mathrm{C} \\
\text { p.E21Q }\end{array}$ & $\begin{array}{l}\text { (Goldmuntz et al., } \\
\text { 2001)/(McElhinney } \\
\text { et al., 2003) } \\
\text { (Elliott et al., 2003) }\end{array}$ & TN domain & alters a conserved amino acid within the $\mathrm{TN}$ domain, damaging & SIFT/Polyphen \\
\hline 3. & $\begin{array}{l}\text { c. } 65 \mathrm{~A}>\mathrm{C} \\
\text { p.Q22P }\end{array}$ & (McElhinney et al., & $\begin{array}{l}5 \text { ' coding } \\
\text { region }\end{array}$ & damaging & SIFT/Polyphen \\
\hline 4. & $\begin{array}{l}\text { c. } 65 \mathrm{~A}>\mathrm{G} \\
\text { p.Q22R }\end{array}$ & $\begin{array}{l}\text { (Draus, Jr. et al., } \\
\text { 2009) }\end{array}$ & $\begin{array}{l}5^{\prime} \text { coding } \\
\text { region }\end{array}$ & damaging & SIFT/Polyphen \\
\hline 5. & $\begin{array}{l}\text { c. } 73 \mathrm{C}>\mathrm{T} \\
\text { p. } \mathrm{R} 25 \mathrm{C}\end{array}$ & $\begin{array}{l}\text { (Benson et al., 1999) } \\
\text { (Goldmuntz et al., } \\
\text { 2001),(McElhinney et } \\
\text { al., 2003) } \\
\text { (Akcaboy et al., } \\
\text { 2008) } \\
\text { (Gioli-Pereira et al., } \\
\text { 2010) (Esposito et al., } \\
\text { 2009) }\end{array}$ & $\begin{array}{l}5 \text { ' coding } \\
\text { region }\end{array}$ & $\begin{array}{l}\text { (Kasahara et al., 2000) } \\
\text { reduced DNA binding affinity as dimer, WT + R25C increase in } \\
\text { transactivation than in WT alone } \\
\text { (Esposito et al., 2009) } \\
\text { EMSA analysis no significant reduction in DNA binding } \\
\text { significant reduction in transactivation activity at lower } \\
\text { concentration of protein (100 ng), but masked at higher } \\
\text { concentration }\end{array}$ & functional assays \\
\hline 6. & $\begin{array}{l}(\mathrm{c} .124 \mathrm{G}>\mathrm{C}) * * \\
\text { p.A } 42 \mathrm{P}\end{array}$ & $\begin{array}{l}\text { (Gioli-Pereira et al., } \\
\text { 2010) }\end{array}$ & $\begin{array}{l}5^{\prime} \text { coding } \\
\text { region }\end{array}$ & tolerated & SIFT/Polyphen \\
\hline 7. & $\begin{array}{l}\text { c. } 188 \mathrm{C}>\mathrm{T} \\
\text { p.A63V }\end{array}$ & $\begin{array}{l}\text { (McElhinney et al., } \\
\text { 2003) }\end{array}$ & $\begin{array}{l}5^{\prime} \text { coding } \\
\text { region }\end{array}$ & tolerated & SIFT/Polyphen \\
\hline
\end{tabular}



8. c. $215221 \mathrm{del}$ AGCTGGG
(Watanabe et al.,
5 ' coding
truncated protein affecting HD, NK-SD
p.E72fs
9. c.223_224delCG
p.R75fs
(p.P77fs)**
10. c. $244 \mathrm{~T}>\mathrm{A}$
p.C82S
2002)
region
(Watanabe et al.,
2002)
5' coding
region
(Esposito et al., 2009) 5' coding region
EMSA analysis no significant reduction in DNA binding significant reduction in transactivation activity at lower
functional assay concentration of protein $(100 \mathrm{ng})$, but masked at higher concentration
Note: according to authors not conclusive!
11. c.262delG p.A88fs
(Hirayama-Yamada et al., 2005)
5 ' coding region
12. c.312delG p.K104fs (p.D105fs)**
(Konig et al., 2006)
5' coding region
13. c. $325 \mathrm{G}>\mathrm{T}$ p.E109X
(Pabst et al., 2008)
5' coding region
14. c. $380 \mathrm{C}>\mathrm{A}$ p.A127E
15. c. $424 \mathrm{C}>\mathrm{T}$ p.R142C
(McElhinney et al., 2003)
5 ' coding region
(Gutierrez-Roelens et HD al., 2006)
16. c. $445 \mathrm{C}>\mathrm{T}$
(Benson et al., 1999) HD

HD

\section{SIFT/Polyphen}
functional assay, ConSurf
functional assay interaction with NKX2-5, GATA4 and TBX5
no DNA binding and transactivation p.Q149X (Bjornstad and Leren, 
2009)

17. (c.479A $>$ C $)^{* *}$ p.Q160P

18. c.498_499 insC p.E167fs

19. c. $508 \mathrm{C}>\mathrm{T}$ p.Q170X

20. c.512T $>\mathrm{C}$ p.L171P

21. c. $533 \mathrm{C}>\mathrm{T}$ p.T178M
(Rifai et al., 2006)

HD

damaging

(Sarkozy et al., 2005)

HD

(Schott et al., 1998)

HD

Kasahara and

Benson, 2004)

(Schott et al., 1998)

(Hirayama-Yamada

et al., 2005)

(Elliott et al., 2003)

HD

WT alone) TBX5 no DNA binding, no transactivation, inhibited transcriptional

(Zhu et al., 2000)

loss of transactivation, WT + Q170X less transactivation than in

WT alone, no DNA binding, diffused localization in nucleus and cytoplasm, inhibited synergistic NKX2-5-GATA4 interaction

(Monzen et al., 2002)

reduced expression and transactivation of cardiac-specific genes, inhibited cardiomyocyte differentiation, promoted stress-induced cell death of cardiomyocytes

(Kasahara and Benson, 2004)

anomalous nuclear localization, reduced DNA-protein binding reduced transactivation, less efficient interaction with GATA4 and

(Kasahara et al., 2000), markedly reduced DNA binding and transactivation

(Zhu et al., 2000)

reduced transactivation, inhibited transcriptional activity of NKX2-5 WT (WT + T178M less transactivation than in WT alone, reduced DNA binding), inhibited NKX2-5-GATA4

synergistic interaction functional assay/

SIFT/Polyphen

in vitro cardiomyocyte

differentiation system

functional assay

in vitro cardiomyocyte

differentiation system 
22. c. $554 \mathrm{G}>\mathrm{T}$ p.W185L

23. c. $561 \mathrm{G}>\mathrm{C}$ p.Q187H

24. c. $564 \mathrm{C}>\mathrm{A}$ p.N188K

25. c. $565 \mathrm{C}>\mathrm{G}$ p.R189G

26. c.568C $>\mathrm{T}$ p.R190C

27. c. $569 \mathrm{G}>\mathrm{A}$ p.R190H
(Sarkozy et al., 2005) HD

(Gutierrez-Roelens et HD al., 2002)

(Benson et al., 1999)

HD

(Benson et al., 1999)

HD

(Hirayama-Yamada

HD

et al., 2005)

(Kasahara and

Benson, 2004)
(Monzen et al., 2002)

reduced expression and transactivation of cardiac-specific genes, inhibited cardiomyocyte differentiation, promoted stress-induced cell death of cardiomyocytes

(Kasahara and Benson, 2004), anomalous nuclear localization, less repressor activity than GAL4-NKX2-5_WT (repressor)

(Inga et al., 2005)

loss-of-function mutant in yeast assay

damaging

\section{SIFT/Polyphen}

(Kasahara and Benson, 2004)

reduced DNA binding, reduced transactivation, reduced

functional assay interaction with TBX5

(Kasahara et al., 2000)

markedly reduced DNA binding and transactivation

(Kasahara and Benson, 2004)

less repressor activity than GAL4-NKX2-5_WT (repressor)

(Kasahara et al., 2000)

markedly reduced DNA binding and transactivation, inhibited transcriptional activity of NKX2-5 WT (WT + R189G much less transactivation than in WT alone)

(Kasahara and Benson, 2004) anomalous nuclear localization damaging

\section{SIFT/Polyphen}

(Kasahara and Benson, 2004)

compartmentalized instead of diffused nuclear localization as in wt, reduced DNA binding, reduced transactivation, reduced interaction with NKX2-5, GATA4 and TBX5 
28. c.572A $>\mathrm{G}$ p.Y191C

(Benson et al., 1999) HD

29. c.592C $>\mathrm{T}$

p.Q198X

\begin{abstract}
(Schott et al., 1998) 3' coding
(Hosoda et al., 1999) region
\end{abstract}

30. c.605_606delTG p.L202fs

31. c.646C $>\mathrm{T}$ p.R216C

32. c. $656 \mathrm{C}>\mathrm{T}$ pA219V

33. InsTCCCT701 (c.701_702insTCCCT) 2003)

D235AFSter

(p.A235fs)**

(Sarkozy et al., 2005) 3' coding region

(Goldmuntz et al., NK2-SD 2001),(McElhinney et domain al., 2003)

(Goldmuntz et al., NK2-SD 2001),(McElhinney et domain al., 2003)

(McElhinney et al., 3' coding region
(Kasahara et al., 2000),(Kasahara and Benson, 2004) markedly reduced DNA binding and transactivation, inhibited transcriptional activity of NKX2-5 WT (WT + Y191C less transactivation than in WT alone)

(Kasahara et al., 2000)

reduced DNA binding affinity as dimer (Zhu et al., 2000)

reduced transactivation, $\mathrm{WT}+\mathrm{Q} 198 \mathrm{X}$ much increased transactivation than in WT alone, enhanced NKX2-5-GATA4

synergistic interaction, overexpression in cultured cardiomyocytes induced apoptosis

(Monzen et al., 2002)

lower cardiomyocyte differentiation efficiency, promoted stressinduced cell death of cardiomyocytes

truncated protein leading to deletion of NK-SD

damaging

(Inga et al., 2005) functional assay

functional assay /

in vitro cardiomyocyte

differentiation system

SIFT/Polyphen

functional assay 


\begin{tabular}{|c|c|c|c|c|c|}
\hline 34. & $\begin{array}{l}\text { c. } 768 \mathrm{~T}>\mathrm{A} \\
\text { p.Y256X }\end{array}$ & $\begin{array}{l}\text { (Gutierrez-Roelens et } \\
\text { al., 2006) }\end{array}$ & $\begin{array}{l}3 \text { ' coding } \\
\text { region }\end{array}$ & $\begin{array}{l}\text { truncated protein with } 68 \text { aa lacking, predicted to affect ability of } \\
N K X 2-5 \text { to form dimers }\end{array}$ & \\
\hline 35. & $\begin{array}{l}\text { c. } 777 \mathrm{C}>\mathrm{A} \\
\text { p.Y259X }\end{array}$ & (Benson et al., 1999) & $\begin{array}{l}3 \text { ' coding } \\
\text { region }\end{array}$ & $\begin{array}{l}\text { (Kasahara et al., 2000) } \\
\text { reduced DNA binding affinity as dimer, reduced transactivation, } \\
\text { inhibited transcriptional activity of NKX2-5 WT (WT + Y259X } \\
\text { much less transactivation than in WT alone) }\end{array}$ & functional assay \\
\hline 36. & $\begin{array}{l}(\mathrm{c} .792 \mathrm{C}>\mathrm{A})^{* *} \\
\text { p.C264X }\end{array}$ & (Ikeda et al., 2002) & $\begin{array}{l}3 \text { ' coding } \\
\text { region }\end{array}$ & truncated protein & \\
\hline 37. & $\begin{array}{l}\text { c. } 823 \mathrm{C}>\mathrm{A} \\
\text { p.P275T }\end{array}$ & $\begin{array}{l}\text { (McElhinney et al., } \\
\text { 2003) }\end{array}$ & $\begin{array}{l}3 \text { ' coding } \\
\text { region }\end{array}$ & damaging & SIFT/Polyphen \\
\hline 38. & $\begin{array}{l}\text { c. } 839 C>T \\
\text { p.P280L }\end{array}$ & (Esposito et al., 2009) & $\begin{array}{l}3^{\prime} \text { coding } \\
\text { region }\end{array}$ & tolerated & SIFT/Polyphen \\
\hline 39. & $\begin{array}{l}\text { delAAC871 } \\
\text { (c.871_873del } \\
\text { AAC)** } \\
\text { del291N } \\
(\text { p.N291del)** }\end{array}$ & $\begin{array}{l}\text { (McElhinney et al., } \\
\text { 2003) }\end{array}$ & $\begin{array}{l}3^{\prime} \text { coding } \\
\text { region }\end{array}$ & deleted amino acid & \\
\hline 40. & $\begin{array}{l}\text { c. } 967 \mathrm{G}>\mathrm{A} \\
\text { p.A323T }\end{array}$ & $\begin{array}{l}\text { (McElhinney et al., } \\
\text { 2003) }\end{array}$ & $\begin{array}{l}3 \text { ' coding } \\
\text { region }\end{array}$ & damaging/tolerated & SIFT/Polyphen \\
\hline 41. & $\begin{array}{l}\text { Int1 DSG+1T } \\
(\text { c. } 334+1 \mathrm{G}>\mathrm{T})\end{array}$ & (Benson et al., 1999) & $\begin{array}{l}\text { intronic, } \\
\text { splice donor } \\
\text { site }\end{array}$ & $\begin{array}{l}\text { (Kasahara et al., 2000) } \\
\text { abolished intron splicing, poor accumulation of mutant protein in } \\
\text { the cell, no DNA binding,and transactivation }\end{array}$ & functional assay \\
\hline
\end{tabular}

